\title{
Molecular and morphological congruence of three new cryptic Neopetrosia spp. in the Caribbean
}

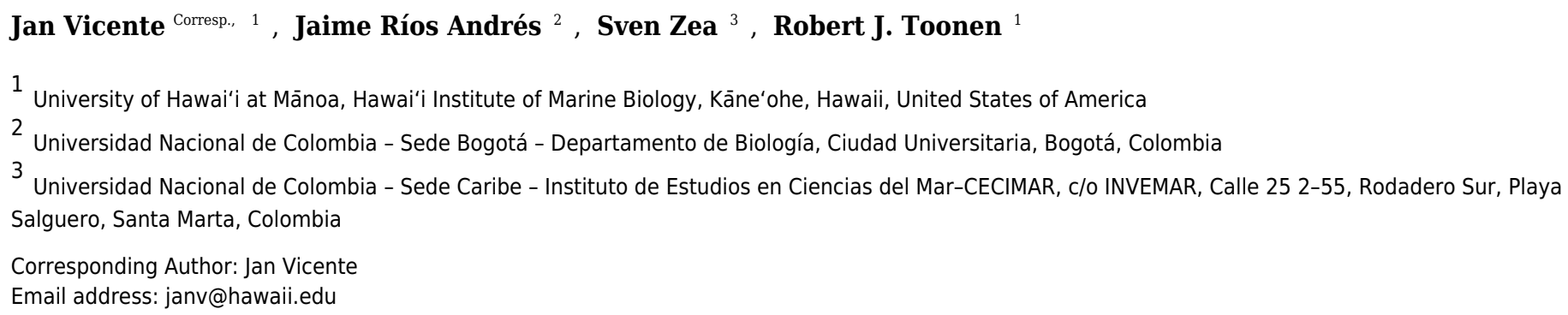

Neopetrosia proxima (Porifera: Demospongiae: Haplosclerida) is described as a morphologically variable sponge common on shallow reefs of the Caribbean. However, the range of morphological and reproductive variation within putative N. proxima led us to hypothesize that such variability may be indicative of cryptic species rather than plasticity. Using DNA sequences and morphological characters we confirmed the presence of three previously undescribed species of Neopetrosia. Morphological differences of each new congener were best resolved by partial gene sequences of the mitochondrial cytochrome oxidase subunit 1 (COI) over nuclear ones (18S rRNA and 28S rRNA). Several new characters for Neopetrosia were revealed by each new species. For example, Neopetrosia dendrocrevacea sp. nov. and Neopetrosia cristata sp. nov. showed the presence of grooves on the surface of the sponge body that converge at the oscula, and a more disorganized skeleton than previously defined for the genus. Neopetrosia sigmafera sp. nov. adds the 1) presence of sigma microscleres, 2) significantly wider/longer oxeas (>200 $\mu \mathrm{m})$, and 3) the presence of parenchymella larvae. Sampling of conspecifics throughout several locations in the Caribbean revealed larger spicules in habitats closer to the continental shelf than those in remote island locations. Our study highlights the importance of integrating molecular and morphological systematics for the discrimination of new Neopetrosia spp. despite belonging to one of several polyphyletic groups (families, genera) within the current definition of the order Haplosclerida. 
1 Molecular and morphological congruence of three

2 new cryptic Neopetrosia spp. in the Caribbean

3

4

5

6

\author{
Jan Vicente ${ }^{1}$, Jaime Ríos Andrés ${ }^{2}$, Sven Zea ${ }^{3}$, Robert J. Toonen ${ }^{1}$ \\ ${ }^{1}$ Hawai'i Institute of Marine Biology, University of Hawai'i at Mānoa, Kāne'ohe, HI, USA \\ ${ }^{2}$ Universidad Nacional de Colombia - Sede Bogotá - Departamento de Biología, Ciudad \\ Universitaria, Bogotá - Colombia
}

${ }^{3}$ Universidad Nacional de Colombia - Sede Caribe - Instituto de Estudios en Ciencias del MarCECIMAR, c/o INVEMAR, Calle 25 2-55, Rodadero Sur, Playa Salguero, Santa Marta Colombia

Corresponding Author:

Jan Vicente ${ }^{1}$

Hawai'i Institute of Marine Biology, University of Hawai'i at Mānoa, Kāne‘ohe, HI, 96744, USA

Email address: janv@hawaii.edu

\title{
Abstract
}

Neopetrosia proxima (Porifera: Demospongiae: Haplosclerida) is described as a morphologically variable sponge common on shallow reefs of the Caribbean. However, the range of morphological and reproductive variation within putative $N$. proxima led us to hypothesize that such variability may be indicative of cryptic species rather than plasticity. Using DNA sequences and morphological characters we confirmed the presence of three previously undescribed species of Neopetrosia. Morphological differences of each new congener were best resolved by partial gene sequences of the mitochondrial cytochrome oxidase subunit 1 (COI) over nuclear ones (18S rRNA and 28S rRNA). Several new characters for Neopetrosia were revealed by each new species. For example, Neopetrosia dendrocrevacea sp. nov. and Neopetrosia cristata sp. nov. showed the presence of grooves on the surface of the sponge body that converge at the oscula, and a more disorganized skeleton than previously defined for the genus. Neopetrosia sigmafera sp. nov. adds the 1) presence of sigma microscleres, 2) significantly wider/longer oxeas ( $>200$ $\mu \mathrm{m}$ ), and 3) the presence of parenchymella larvae. Sampling of conspecifics throughout several locations in the Caribbean revealed larger spicules in habitats closer to the continental shelf than those in remote island locations. Our study highlights the importance of integrating molecular and morphological systematics for the discrimination of new Neopetrosia spp. despite belonging to one of several polyphyletic groups (families, genera) within the current definition of the order Haplosclerida. 


\section{Introduction}

41 Cryptic species have posed a challenge to taxonomy and biodiversity studies for over 300 years,

42

43

44

45

46

47

48

49

50

51

52

53

54

55

56

57

58

59

60

61

62

63

64

65

66

67

68

69

70

71

72

73

74

75

76

77

78

but access to DNA sequencing has provided relatively simple tools to resolve species boundaries among morphologically similar species (Bickford et al. 2007; Stat et al. 2012). Particularly for taxa belonging to highly diverse orders with variable growth forms and limited morphological characters, such as corals and sponges, the integration of molecular and morphological approaches can be invaluable (Wörheide \& Erpenbeck 2007; Concepcion et al. 2008; Forsman et al. 2009). In sponges, congruence of molecular and morphological datasets have been successful at the subclass level and have reclassified Demospongiae into subclasses Verongimorpha, Keratosa, and the Heteroscleromorpha (Borchiellini et al. 2004; Sperling et al. 2009; Cárdenas et al. 2012; Morrow \& Cárdenas 2015). The presence of siliceous megascleres (monaxons and/or tetraxons) and highly diversified microscleres as synapomorphic characters in Heteroscleromorpha were substantiated by partial nuclear gene sequences (28S rRNA and 18S rRNA) and mitochondrial gene sequence (Holmes \& Blanch 2007; Lavrov et al. 2008). However, congruence of morphological and molecular datasets for lower taxonomic classifications within Heteroscleromorpha (> 6,800 species) have been unsuccessful. Most species within Heteroscleromorpha belong to the order Haplosclerida (1,101 species) (Morrow \& Cárdenas 2015; Van Soest et al. 2018). Although mitochondrial and nuclear genes show Haplosclerida to form a well-supported divergent clade from Heteroscleromorpha (Lavrov et al. 2008; Thacker et al. 2013), almost every family within Haplosclerida is polyphyletic (Redmond et al. 2011, 2013).

Among these polyphyletic families is the Petrosiidae, which currently consists of 212 species with most of these belonging to Petrosia (Vosmaer 1885) (120 species), followed by Xestospongia (De Laubenfels 1932) (57 species), Neopetrosia (De Laubenfels, 1949) (33 species) and Acanthostrongylophora (Hooper 1984) (2 species) (Van Soest et al. 2018). Xestospongia and Neopetrosia are mainly distinguished on the basis of spicule size, the former usually having spicules larger than $200 \mu \mathrm{m}$ and the latter shorter. Neopetrosia congeners are distributed worldwide and nine are found in the Tropical Western Atlantic. These include $N$. carbonaria (Lamarck, 1814), N. subtriangularis (Duchassaing 1850), N. proxima (Duchassaing \& Michelotti, 1864), N. rosariensis (Zea \& Rützler, 1983), N. dominicana (Pulitzer-Finali 1986), and N. sulcata (Santos et al. 2016), which are found in shallow to deep reefs; and N. dutchi (Van Soest et al. 2014), N. eurystomata (Van Soest et al. 2014), and N. ovata (Van Soest et al. 2014), which are recently discovered mesophotic reef species. Mitochondrial and nuclear sequence data have been published for eight congeners which deeply diverge from one another and are polyphyletic (Redmond et al. 2011; Thacker et al. 2013, Redmond et al. 2013). Mindful of the polyphyletic nature of Neopetrosia, our purpose for this study was not to find markers that resolve the monophyly for this genus but rather use a pairwise comparison of mitochondrial and nuclear DNA sequences of our material with those from GenBank to confirm molecular and morphological separation for new congeners in the Caribbean. 
79

80

81

82

83

84

85

86

87

88

89

90

91

92

93

94

95

96

97

98

99

100

101

102

103

104

105

106

107

108

109

110

111

112

113

114

115

116

117

118

Among tropical W. Atlantic Neopetrosia, N. proxima is a rather widespread species, distributed from the Bahamas to Northern Brazil and shows considerable habitat and geographical variability (Zea 1987, Zea et al. 2014). In fact, detailed morphological revision of material previously considered to belong to this species has yielded new species (Santos et al. 2016). In this study, Santos and colleagues distinguished N. sulcata from N. proxima by noticing a digitate morphology, lighter color tones with no differentiation between the ectosome and choanosome. While reviewing material of what was believed to be $N$. proxima or close relatives from Colombia, Panamá and Martinique, we found several morphologically distinct morphotypes. After detailed molecular barcoding with partial sequence of the cytochrome oxidase subunit 1 (CO1), 28S rRNA, and 18S rRNA and morphological comparisons, we were able to distinguish three new species from morphologically similar N. proxima, which we describe and compare here.

\section{Materials \& Methods}

Specimen collection. Sponges were photographed in situ and collected in Bocas del ToroPanamá, Colombia and Martinique at depths ranging between 4 and $36 \mathrm{~m}$. Specimens from Colombia were collected at Golfo de Urabá, Cartagena and Santa Marta on the South American coast, and the San Andrés/Old Providence Archipelago in the SW Caribbean. Field observations (in vivo) of each specimen's morphology, color, consistency, surface, oscules, exudates, and odors were recorded. Samples were preserved in $95 \%$ ethanol, and $4 \%$ paraformaldehyde (PFA) for histological examination. Samples preserved in PFA for 2-3 days were later transferred to 70 $\%$ ethanol.

Type and other specimens were deposited in the Florida Museum of Natural History (catalogue number beginning with acronym UF) in Florida, USA, the Makuriwa Museum of Marine Natural History of Colombia at the Institute of Marine and Coastal Research (acronym INV POR) and the Natural Science Institute at the National University of Colombia in Bogota - INVEMAR [acronym ICN-MHN(Po)]. Fragments were also deposited in the Zoological Museum of Amsterdam at the Naturalis Biodiversity Center in Leiden, Netherlands (acronym ZMA.POR). Fragments of specimens collected in Panamá were deposited in the Museum of Marine Biology and Limnology at the University of Panamá as required by the collection permit of fauna Nr. 5 issued by the "Autoridad Nacional del Ambiente (ANAM)". Collecting in Colombia was carried out under Decree 309-2003 of the Ministry of the Environment and Sustainable Development as part of the ongoing project "Sponges of the Colombian Caribbean" of INVEMAR's Makuriwa Museum. Some uncatalogued samples were studied during the "Porifera Tree of Life Project Workshop" in Bocas del Toro, Panamá, August 2012. Uncatalogued samples from Martinique were studied during the "2013 Training Course on the sponge biodiversity of the Caribbean Sea, workshop of La Martinique" and the "Kick-off meeting of the Associated International

Laboratory MARRIO” in December 2013 (see also Pérez et al. 2017). 
119 DNA extraction, sequencing and phylogenetic analysis. Sponge pieces (30 $\mathrm{mg})$ were removed

120

121

122

123

124

125

126

127

128

129

130

131

132

133

134

135

136

137

138

139

140

141

142

143

144

145

146

147

148

149

150

151

152

153

154

155

156

157

158

from type material (preserved in 95\% ethanol) collected in Panamá (UF 3854, UF 3856-3860)

and were used for DNA extractions. DNA was extracted using the Promega E.Z.N.A. Tissue

DNA Kit, following the manufacturer's instructions. DNA concentrations were checked by absorbance ratios using a UV-visible spectrophotometer (Thermo Scientific NanoDrop). DNA from the first elution was diluted to a working stock concentration of $35 \mathrm{ng} \mu \mathrm{L}^{-1}$.

A list of primers for Polymerase Chain Reaction (PCR) amplification targeting fragments of the cytochrome oxidase subunit 1 (COI), the D1-D2 region of the 28S rRNA gene sequence, and the 18S rRNA gene sequence are provided in Table S1. Partial sequences of the different Neopetrosia spp. were made possible using previously reported primer combinations in our PCR reactions (Folmer et al. 1994; Kelly-Borges \& Pomponi 1994; Geller et al. 2013; Chombard et al. 1998). Specific primers were then designed using NetPrimer (http://www.premierbiosoft.com/netprimer/netprlaunch/netprlaunch.html) when sequence data was missing to complete the gene sequence region of interest.

Polymerase chain reactions were carried out in $25 \mu$ total volume including the following: $9 \mu \mathrm{L}$ of $\mathrm{H}_{2} \mathrm{O}, 12.5 \mu \mathrm{L}$ of BioMix ${ }^{\mathrm{TM}}$ Red (Bioline, Taunton, MA) PCR Mastermix, $0.5 \mu \mathrm{L}$ of each primer $(10 \mathrm{mM}), 2 \mu \mathrm{L}$ of BSA $(100 \mu \mathrm{g} / \mathrm{ml})$, and $0.5 \mu \mathrm{L}$ of template DNA. The PCR program consisted of an initial denaturation at $94{ }^{\circ} \mathrm{C}$ for 3 min followed by 35 cycles of $94{ }^{\circ} \mathrm{C}$ for $30 \mathrm{sec}$, annealing temperatures ranged between 45 and $60{ }^{\circ} \mathrm{C}$ for $30 \mathrm{sec}$ to $1 \mathrm{~min} 30 \mathrm{sec}$ depending on the primer combination and gene product of interest, and 1 minute extension at $72{ }^{\circ} \mathrm{C}$. A final extension at 72 ${ }^{\circ} \mathrm{C}$ for 8 min finished the reaction. Primer combinations and annealing temperature for each PCR product is listed in Table S2. PCR products were all ran on a $1 \%$ agarose gel stained with GelRed and purified using EXOFAP (EXO1 and FastAP). Sequencing reactions were performed using the BigDye TM terminator v. 3.1, and sequencing was done with an ABI Prism 3730XL automated sequencer.

Forward and reverse reads were sequenced to achieve the greatest base calling accuracy for each species and targeted gene fragment. Sequence chromatograms in forward and reverse directions were trimmed (at an error probability limit of 0.05). Chromatograms were then assembled and edited by eye using Geneious 10 (Kearse et al. 2012). Base calling while editing was made using the highest confidence score for any given base on one of the two chromatograms. All assembled chromatograms resulted in $>90 \%$ high quality base pair reads with a mean Phred quality score $\geq 40$. Assembled sequences were saved and exported as a fasta file. Each fasta file from targeted gene sequences and each Neopetrosia spp. were checked for contamination using the BLAST (Altschul et al. 1990) function from GenBank. BLAST results that showed $>85 \%$ sequence identity and a query cover of $>60 \%$ to those belonging to Porifera were exported to Geneious 10 and aligned using the ClustalW function with default parameters. Alignments were generated using $439 \mathrm{bp}$ of the COI gene sequence, 821 bp of the D1-D2 region of the 28S rRNA 
159

160

161

162

163

164

165

166

167

168

169

170

171

172

173

174

175

176

177

178

179

180

181

182

183

184

185

186

187

188

189

190

191

192

193

194

195

196

197

198

and $638 \mathrm{bp}$ for the $18 \mathrm{~S}$ rRNA gene sequence. Phylogenetic trees were rooted on outgroups Baikalospongia intermedia DAQ167168.1, Axinella corrugata KC869523.1 and EF092264.1 for COI, 28S rRNA and 18S rRNA, respectively. A plugin for MrBayes version 3.2.1 (Huelsenbeck \& Ronquist 2001) for Bayesian inference (BI) and RaxML (Stamatakis 2006) was added for phylogenetic analyses using a maximum likelihood (ML) framework in Geneious 10. Both analyses were implemented using the GTRGAMMA model with 1,000 bootstrap replicates. The Bayesian inference was run using 5 million generations sampled every 200 generations. The analysis was stopped when the standard deviation of split frequencies fell below 0.01 . At this point convergence was assumed and the burnin value was determined. Phylogenetic trees were generated in Mega7 (Kumar et al. 2016). Resulting bootstrap values of $>50$ from the ML and Bayesian posterior probabilities $>0.50$ from the $\mathrm{BI}$ analysis were incorporated to the tree. Sequences of holotypes and other specimens for each species collected in Panamá were deposited in GenBank and assigned accession numbers reported in Table S3.

\section{Sectioning and spicule preparation}

Permanent slides with clean spicules and thick $(\sim 1 \mathrm{~mm})$ histological sections (tangential and perpendicular) were prepared for each specimen following the methods in Zea (1987). Spicules were digested from small $(20 \mathrm{mg})$ sponge pieces soaked in commercial sodium hypochlorite and shaken for 12 hours. Spicules were subsequently washed and centrifuged three times with DI and resuspended in ethanol; a few drops of spicule suspensions were added to microscope slides, dried on a warm plate, and mounted on Permount ${ }^{\circledR}$. Tissue sections were either dried on a warm plate or dehydrated and stained in successively stronger ethanol solutions $(96 \%, 100 \%)$, and then cleared in xylene; then sections were mounted on Permount ${ }^{\circledR}$. Individual spicule types and skeletal framework were photographed with a Zeiss AxioCam ERc5s mounted on a Zeiss AxioLabA.1 light microscope (LM). Photographs were processed in Photoshop and measurements carried out from photos with AxioVision SE64 Rel.4.9.1 and ImageJ ${ }^{\circledR}$ (Abràmofff et al. 2005) (http://imagej.nih.gov/ij/). The lengths and widths of 50 spicules per specimen and spicule types are presented as [minimum-mean $[ \pm 1$ standard deviation (SD)]maximum length / width in $\mu \mathrm{m}]$. A few drops of the spicule suspension from Panamanian specimens were added to a stub, air dried, and imaged under high vacuum with a JEOL 5600 SEM Scanning Electron Microscope (SEM) at the Nano Imaging Facility, University of Maryland Baltimore County. Spicule suspension from Colombian and Martinique specimens were carbon coated with a Quorum Q150R and photographed under a QUANTA 200 FEI SEM. Measurements of spicule tracts, skeletal arrangement of fibers, and meshes were compared across species and specimens from different collection sites.

The electronic version of this article in Portable Document Format (PDF) will represent a published work according to the International Commission on Zoological Nomenclature (ICZN), and hence the new names contained in the electronic version are effectively published under that Code from the electronic edition alone. This published work and the nomenclatural acts it 
199

200

201

202

203

204

205

206

207

208

209

210

211

212

213

214

215

216

217

218

219

220

221

222

223

224

225

226

227

228

229

230

231

232

233

234

235

236

237

238

contains have been registered in ZooBank, the online registration system for the ICZN. The ZooBank LSIDs (Life Science Identifiers) can be resolved and the associated information viewed through any standard web browser by appending the LSID to the prefix http://zoobank.org/. The LSID for this publication is: [urn:lsid:zoobank.org:pub:B56217F8-FA57-4D93-8A69BEC98F4B2AE7]. The online version of this work is archived and available from the following digital repositories: PeerJ, PubMed Central and CLOCKSS.

\section{Results}

Phylogenetic analysis. The phylogenetic relationship between novel Neopetrosia spp. using mitochondrial (COI) and nuclear genes (28S rRNA/18S rRNA) reconfirmed the polyphyletic nature of this genus (Erpenbeck et al. 2007; Redmond et al. 2011; Setiawan 2014, 2018) (Fig. 1). Nevertheless, the use of different markers allowed us to detect enough genetic differences across all $N$. proxima paratypes and new Neopetrosia spp. In particular, COI showed the highest resolution of sequence dissimilarity between all new congeners and confirmed our hypothesis that morphological variability was indicative of cryptic species. (Fig. $1 \mathrm{~A}$ ). For example, $N$. proxima, " $N$. dendrocrevacea sp. nov." and " $N$. cristata sp. nov." were all closely related and formed a divergent clade that was closely related (87\% identical) to Amphimedon queenslandica sequence EU237474.1 (Hooper \& Van Soest 2006; Kayal \& Lavrov 2008). Within this clade all $N$. proxima morphotypes were $100 \%$ identical to each other, $96 \%$ identical to " $N$. dendrocrevacea sp. nov.", $95 \%$ identical to " $N$. cristata sp. nov.", and $81 \%$ identical to " $N$. sigmafera sp. nov.". "Neopetrosia sigmafera sp. nov." was the most distantly related ( $<85 \%$ sequence similarity) congener with a well-supported and deeply divergent clade. The closest relative to "N. sigmafera sp. nov." was Gelliodes wilsoni (Carballo et al. 2013) with $99 \%$ identity. Additional congeners like $N$. exigua (Kirkpatrick 1900) sequence KX454496.1 and $N$. seriata (Hentschel 1912) sequence JN242213.1, were distantly related $(<85 \%)$ from all new congeners in this study.

The phylogenetic tree of the $28 \mathrm{~S}$ rRNA gene showed a very similar topology to COI. For example, as in COI, a well-supported clade (1/100) with all specimens of $N$. proxima, " $N$. dendrocrevacea sp. nov." and "N. cristata sp. nov.", were also deeply divergent from the rest of the congeners in the tree (Fig. 1 B). Nonetheless, 28S rRNA did show a lower resolution of sequence dissimilarity, with no sequence differences between " $N$. cristata sp. nov." and " $N$. dendrocrevacea sp. nov." Both sequences of these species were $97 \%$ identical, with strong support (1/100), to all $N$. proxima morphotypes in the clade. All congeneric sequences in this clade were 93-94 \% identical to Petrosia lignosa (Wilson 1925) KC869595.1. In addition, " $N$. sigmafera sp. nov." showed $<85 \%$ sequence identity to all congeners in this clade. The closest relatives to "N. sigmafera sp. nov." were Gelliodes callista (De Laubenfels 1954) KC869562.1 (89 \% identical) and Xestospongia deweerdtae (Lehnert \& Van Soest 1999) KX668524.1 (90\% identical). Additional sequences from congeners like Neopetrosia rosariensis (Zea \& Rützler 1983) KC869457.1 and Neopetrosia subtriangularis (Duchassaing 1850) KC869591.1, were <85 
$239 \%$ identical to all new species. The closest congener to " $N$. sigmafera sp. nov." appears to be

240 Neopetrosia carbonaria (Lamarck 1814) with $88 \%$ sequence identity.

241 The phylogeny of Neopetrosia spp. using 18S rRNA resulted in the lowest resolution of

242 sequence dissimilarity with four congeners being $100 \%$ identical and grouping into Clade $\mathrm{C}$

243 (Redmond et al. 2011) (Fig. 1 C). Identical congeners include "N. cristata sp. nov.", N. proxima,

$244 N$. exigua, and "N. dendrocrevacea sp. nov.". The sequence from " $N$. sigmafera sp. nov." was

$24593 \%$ identical to congeners in Clade $\mathrm{C}$, and grouped into Clade $\mathrm{B}$, which also included $N$.

246 carbonaria. N. rosariensis grouped into Clade A and was $95 \%$ identical to congeners in Clade

247 C, and $97 \%$ identical to "N. sigmafera sp. nov.".

248

249

Systematics

250

251

Class Demospongiae Sollas, 1885

252

253

Subclass Heteroscleromorpha Cárdenas et al. 2012

254

255

\section{Order Haplosclerida Topsent, 1928}

256

257

258

259

260

261

262

263

264

265

266

267

268

269

270

271

272 Thalysias proxima Duchassaing \& Michelotti, 1864: 84, Pl. VIII, Figs. 2-3.

273 Densa araminta De Laubenfels, 1934: 14.

274 Neofibularia proxima; Wiedenmayer, 1977: 147, 255.

275 Xestospongia proxima; Van Soest et al. 1983: 198; Van Soest et al. 1984: 143; Zea, 1987: 116, 276 Fig. 34, pl. IX, Figs. 3-4; Van Soest \& Stentoft 1988: 132, pl. XII Fig. 4, text, fig. 64; Lehnert \&

277 Van Soest 1996: 77, Fig. 29; Díaz, 2005: 470; Collin et al. 2005: 648; Rützler et al. 2000: 278. 
278 Neopetrosia proxima; Campos et al. 2005: 13, Figs. 8A-D; Muricy et al. 2011: 106 (with further 279 synonyms from Brazil); Zea et al. 2014 (field guide); Santos et al. 2016: 336, Fig. 4; Van Soest, 280 2017: 35, Fig. 21a-d; Pérez et al. 2017: 10.

281

282

283

284

285

286

287

288

289

290

291

292

293

294

295

296

297

298

299

300

301

302

303

304

305

306

307

308

309

310

311

312

313

314

315

316

317

Material examined. Bocas del Toro, Panamá: UF 3856, Punta Caracol $\left(9.3777^{\circ} \mathrm{N}, 82.1265^{\circ} \mathrm{W}\right)$ $8 \mathrm{~m}$ in depth, coll. Jan Vicente, May 8, 2015; UF 3858 and UF 3860 Dolphin Rock $\left(9.35076^{\circ} \mathrm{N}\right.$, $\left.82.1863^{\circ} \mathrm{W}\right), 14 \mathrm{~m}$ in depth coll. Jan Vicente and Arcadio Castillo May 20, 2015. Uncatalogued fragments PPA 35, 37 and 38, Isla Colón, Aeropuerto $\left(9.3339^{\circ} \mathrm{N}, 82.2548^{\circ} \mathrm{W}\right)$, on rubble and sand, fringing reef, $7 \mathrm{~m}$ in depth, coll. Sven Zea, August 9, 2012. Colombia: INV POR1304,

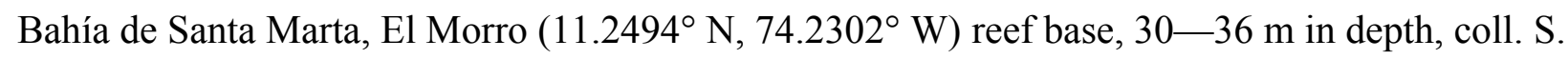
Zea, February 10, 1988. INV POR1306, San Andrés Archipelago Old Providence, north of Low Cay (Pallat Bank, $13.5525^{\circ} \mathrm{N}, 81.3245^{\circ} \mathrm{W}$ ), fore reef terrace, $25 \mathrm{~m}$ in depth, coll. Sven Zea, 19 October 1994. (Further Colombian material is described in Zea 1987.)

Description (Fig. 1, Table 1). The external morphology varies from cylindrical (Fig. 2 A) or flat branching individuals (from $5 \times 15 \mathrm{~cm}$ by $5 \mathrm{~cm}$ thick), to thickly encrusting $(2 \mathrm{~cm}$ thick) mounds (Fig. 2 B, C); encrusting specimens often fill cavities and appear level with the substratum. Oscule size varies between 2 and $7 \mathrm{~mm}$ in diameter and are either randomly scattered along the body of the sponge (Fig. 2 A, C), or aligned along elevated ridges (Fig. 2 B). A white membrane collar surrounding the oscules was observed in some individuals (Fig. 2 C). Consistency is toughly compressible but difficult to cut with a scalpel or a knife. The surface texture is velvety, from even and smooth (Fig. 2 A) to rugged (Fig. 2 B, C), often knobby from conical or blunt elevations around oscules; massive specimens often have keyhole to irregular grooves. All individuals produced a sticky substance when cut or squeezed in situ. Surface color across individuals from Panamá varied from yellow (Fig. 2A), dark brown (Fig. 2 B), to light purple (Fig. 2 C); Santa Marta specimens in Colombia are characteristically violet to pink (see Zea 1987); in other areas color is predominantly yellowish to purplish dark brown. Internal coloration across all specimens is light-yellow.

Skeleton. The skeleton consists of a fasciculated reticulation of isotropic multispicular tracts that form circular to irregularly elongated meshes. In the ectosome, a paratangential reticulation of tracts $(20-200 \mu \mathrm{m})$ makes meshes that vary between 120 and $400 \mu \mathrm{m}$ in diameter (Fig. $2 \mathrm{D}-\mathrm{F}$; Fig. S1 A-C) depending on the individual [(180-300 $\mu \mathrm{m}$ (Fig. 2 D), 80-240 $\mu \mathrm{m}$ (Fig. 2 E), and 280-390 $\mu \mathrm{m}$ (Fig. 2 F)]. Smaller circular meshes in the ectosome seem to be the result of thicker spicule tracts (80-170 $\mu \mathrm{m}$ Fig. $2 \mathrm{E}$; Fig. S1 B), when compared to individuals with thinner spicule tracts (50-100 $\mu \mathrm{m}$ Fig. 2 D-F; Fig. S1 A-C). Dark purple pigments from cyanobacteria penetrate about $750 \mu \mathrm{m}$ into the choanosome (Fig. 2 G, 2 H; Fig. S1 D, E). In some individuals, pigments were not observed from the surface but $500 \mu \mathrm{m}$ below the ectosome (Fig. 2 I; Fig. S1 F). The ectosome can also be distinguished by the presence of large $(500 \mu \mathrm{m})$ subectosomal spaces, clearly visible in some individuals (Fig. 2 G, I; Fig. S1 D, F), but in others it forms 
318

319

320

321

322

323

324

325

326

327

328

329

330

331

332

333

334

335

336

337

338

339

340

341

342

343

344

345

346

347

348

349

350

351

352

353

354

355

356

smaller $(250 \mu \mathrm{m})$ openings (Fig. $2 \mathrm{H}$; Fig. S1 E) as a result of denser and thicker spicule tracts. Erect ascending spicule brushes radiate at the ectosome surface. The choanosome also shows a large number of circular meshes that vary in abundance and size $(200-700 \mu \mathrm{m})$ according to the thickness of spicule tracts (Fig. 2 G-I; Fig. S1 G-I).

Spicules. Most spicules are slightly curved, symmetric oxeas with very few strongyloxeas present (Fig. $2 \mathrm{~J}-\mathrm{L}$ ); some are more curved and there is variation in size with developmental stage. Oxea endings vary between hastate and conical shapes. Size $92-205 \mu \mathrm{m}$ long by 1.7-12 $\mu \mathrm{m}$ wide (Table 1).

Habitat and ecology. This species is found living from shallow rocky shores and reefs, to deep reef habitats in a variety of wave-exposures (Zea 1987, Zea et al. 2014); also, in caves (Pérez et al. 2017). Specimens UF 3858 and UF 3860 were collected in a highly exposed reef (Dolphin Rock) with strong wave energy, while specimen UF 3856 was collected inside Almirante Bay (Punta Caracol) with very low wave exposure. Strong wave energy is known to influence the appearance of aligned oscula (observed in Xestospongia deweerdtae collected in the same site, see Fig. 7B of Vicente et al. 2016) and is apparent in specimen UF 3856. Brooding larvae were not observed in any specimens; zoanthids were also absent.

Distribution. Bahamas (Zea et al. 2014). Caribbean: Puerto Rico, U.S. Virgin Islands, Jamaica, Martinique, Barbados, Panamá, Colombia, Belize, (Zea, 1987, Van Soest \& Stentoft 1988, Lehnert \& van Soest 1996; Rützler et al. 2000, Díaz 2005, Collin et al. 2005, Zea et al. 2014, Pérez et al. 2017). Guyana (Van Soest 2017). Brazil: North to North East Regions (Amapa, Maranhão, Rio Grande do Norte and Sergipe states) (Campos et al. 2005, Muricy et al. 2011, Santos et al. 2016).

Taxonomic remarks. All Neopetrosia proxima specimens collected in this study exhibited varied morphologies (physical appearance, color, thickness of fiber tracts, circular meshes). These differences initially lead us to think that these were heterospecific. However, these variations showed no nuclear or mitochondrial genetic differences, and seem to be plastic characters within this species. Upon closer examination, spicule sizes, spicule shapes, the skeletal arrangement of the choanosome and ectosome are all in agreement with previous descriptions (e.g., Zea 1987, Diaz 2005, Zea et al. 2014).

\section{Neopetrosia dendrocrevacea sp. nov.} (Fig. 3, Fig. S2; Table 1)

Haplosclerida unident. sp. 1; Zea 2001, Table 1.

Neopetrosia sp. -“soft"; Zea et al. 2014 (field guide). 
357

358

359

360

361

362

363

364

365

366

367

368

369

370

371

372

373

374

375

376

377

378

379

380

381

382

383

384

385

386

387

388

389

390

391

392

393

394

395

396

?Neopetrosia proxima; Zea et al. 2014 (field guide, in part, only two images of partly branching and knobby individuals, taken in Panamá, Bocas del Toro, Isla Solarte, Punta Hospital, March 3, 2012, identified from fresh spicule preparations).

Type material and type locality. Holotype: UF 3854, Panamá, Bocas del Toro, STRI point $\left(9.3429^{\circ} \mathrm{N}, 82.1258^{\circ} \mathrm{W}\right), 2 \mathrm{~m}$ in depth, coll. Jan Vicente, June 10, 2015. Paratypes: Colombia: ICN-MHN(Po) 0269, Bahía de Nenguange, playa del Manglar, Santa Marta $\left(11.2494^{\circ} \mathrm{N}\right.$, $\left.74.2301^{\circ} \mathrm{W}\right), 1.5 \mathrm{~m}$ in depth, coll. Sven Zea, March 18, 1999. INV POR1335, Bahía de Chengue $\left(11.3200^{\circ} \mathrm{N}, 74.1267^{\circ} \mathrm{W}\right), 1.5 \mathrm{~m}$ in depth, coll. Sven Zea, May 19, 1982. INV POR1336, Bancos de Salmedina, Cartagena (10.3735 N, $\left.75.6663^{\circ} \mathrm{W}\right), 24 \mathrm{~m}$ in depth, coll. Sven Zea, August 19, 1980. INV POR1337, Islas del Rosario, Isla Rosario $\left(10.1583^{\circ} \mathrm{N}, 75.8050^{\circ} \mathrm{W}\right), 8 \mathrm{~m}$ in depth, coll. Sven Zea, March 7, 1998. INV POR0535, Cabo Tiburón, Golfo de Urabá (8.6840 N, 77.3710 $\left.{ }^{\circ} \mathrm{W}\right), 9 \mathrm{~m}$ in depth, coll. Sven Zea, September 28, 1995. INV POR1333, Isla de Providencia, San Andrés Archipelago (13.5058 $\left.\mathrm{N}, 81.3558^{\circ} \mathrm{W}\right), 16 \mathrm{~m}$ in depth, coll. Sven Zea, October 21, 1994. INV POR 1334, Banco Serrana, leeward terrace, San Andrés Archipelago $\left(14.4592^{\circ} \mathrm{N}, 80.2740^{\circ} \mathrm{W}\right), 16 \mathrm{~m}$ in depth, coll. Sven Zea, May 14, 1995.

Additional material. Bocas del Toro, Panamá: uncatalogued sample PPA 07, Isla Bastimentos, Adriana's reef $\left(9.2419^{\circ} \mathrm{N}, 82.1736^{\circ} \mathrm{W}\right), 5 \mathrm{~m}$ in depth, coll. Sven Zea, March 2, 2012.

Description. Thin to thick $(1 \mathrm{~cm})$ encrustations growing up to $30 \mathrm{~cm}$ in diameter; or made up of coalescing, $1-2 \mathrm{~mm}$ thick branches, elevating to $10-15 \mathrm{~cm}$ from the base (Fig. $3 \mathrm{~B}$ ). The surface has densely reticulated or scattered characteristic grooves that converge at the rim of the oscules, cutting through them and making them appear lumpy or incomplete (Fig. $3 \mathrm{~A}-\mathrm{C}$ ); sometimes the grooves surround smooth knobs of varied sizes. Oscular diameter range from 1-2 $\mathrm{mm}$ in encrusting individuals to $0.5 \mathrm{~cm}$ in branching ones. A translucent membrane surrounds the oscules, sometimes closing them. Consistency from slightly soft to firm, but crumbly. Texture is particularly velvety and when squeezed in situ the sponge produces a sticky substance. External color is golden yellow to reddish brown to dark purple with ochre yellow tinges; light-yellow in ethanol. Interior color light-yellow.

Skeleton. Ectosome as a paratangential reticulation, composed of rather confused, loose, uni to paucispicular tracts, up to 4-10 spicules and 25-70 $\mu \mathrm{m}$ across, forming polygonal meshes 100 $200 \mu \mathrm{m}$ in diameter (Fig. 3 D-F; Fig. S2 A-C). Single spicules and spicule brushes from the end of choanosomal ascending tracts pierce the surface. Pigments from cyanobacteria penetrate about $600 \mu \mathrm{m}$ inside the choanosome. The choanosome consists of an anisotropic reticulation with distinguishable, but loose primary tracts, $6-13$ spicules and $10-50 \mu \mathrm{m}$ across, separated by 50-200 $\mu \mathrm{m}$ (Fig. $3 \mathrm{G}-\mathrm{I}$; Fig. S2 D-F). Tracts are interconnected by solitary spicules or loose paucispicular tracts, forming confused meshes measuring $80-300 \mu \mathrm{m}$ in diameter (Fig. $3 \mathrm{G}-\mathrm{I}$; Fig. S2 G-I). 
Spicules. Symmetric oxeas, curved, with hastate endings (short but thick pointed ends, 86-198

400

401

402

403

404

405

406

407

408

409

410

411

412

413

414

415

416

417

418

419

420

421

422

423

424

425

426

427

428

429

430

431

432

433

434

435 $\mu \mathrm{m}$ long by $2.8-10.5 \mu \mathrm{m}$ wide (Table 1 ). Spicule sizes vary by geographic location. For example, spicules from specimens collected closer to the continental shelf (i.e. Urabá ) measured $171.4 \pm 12.9 \mu \mathrm{m} \times 7.4 \pm 1.0 \mu \mathrm{m}$ while those collected on the insular shelf (i.e. San Andrés Archipelago) were smaller and measured 130.1 $\pm 7.7 \mu \mathrm{m} \times 3.8 \pm 0.6 \mu \mathrm{m}$ (Table 1, Fig. $3 \mathrm{~J}-\mathrm{N}$ ).

Habitat and ecology. This species is found on shallow rocky substrates $(1.5 \mathrm{~m})$ and deep reefs $(16 \mathrm{~m})$, living on dead coral rubble or over other sponges. This species is a common sponge of the leeward fore reef terrace of Banco Serrana in the San Andrés Archipelago with an average density of 0.56 individuals per $20 \mathrm{~m}^{2}$ (Zea 2001).

Distribution. Panamá (Bocas del Toro), Colombia (Urabá, Cartagena, Santa Marta, San Andrés Archipelago, cf. Zea 2001), Puerto Rico (Zea et al. 2014). S.Z. examined a dried fragment from the Bay of Honduras which belongs to this species (courtesy of J.C. Lang).

Taxonomic remarks. Although some specimens initially analyzed showed different characteristics from Neopetrosia proxima, like Haplosclerida unident. sp. 1 (Zea 2001), or as Neopetrosia sp.-"soft" (Zea et al. 2014), others were thought to be $N$. proxima [e.g., ICNMHN(Po) 0269 and INV POR1335]. Accordingly, a more detailed molecular and morphological analysis was pursued to detect less obvious differences. COI sequence data of Neopetrosia dendrocrevacea was $96 \%$ identical to $N$. proxima and confirmed heterospecificity to $N$. proxima (Fig. 1). Some obvious morphological differences between these species lie in the consistency of individuals, where $N$. proxima is generally firmer and tougher to cut than $N$. dendrocrevacea sp. nov. Neopetrosia proxima also exudes a stickier mucus when cut. Oscules are larger in $N$. proxima and the surface lacks the grooves that seem to be a diagnostic morphological character of $N$. dendrocrevacea sp. nov. The arrangement of the choanosomal and ectosomal skeleton shows very distinct morphologies from $N$. proxima, with reticulation being more isotropic in $N$. proxima. Meshes are also larger in diameter and better organized in N. proxima; multispicular tracts are thicker, more dense and fasciculated as described by Campos et al. (2005) and Zea (1987). In the field, $N$. dendrocrevacea sp. nov. can be easily confused with Svenzea cristinae Alvarez, van Soest \& Rützler, 2002 which is also a crumbly, thin to thicker encrustation with yellow tinges, but its spicules are long styles (Zea et al. 2014). N. dendrocrevacea sp. nov. also shares some similar external features with Haliclona (Soestella) walentinae Diaz, Thacker, Rützler \& Piantoni, 2007 including the sometimes bumpy surface between shallow grooves, and the similar oxea (100-180 x 3-9 $\mu \mathrm{m})$. The latter are more thinly encrusting and soft, has a looser and more unispicular skeleton, and the tissue is crisscrossed by purple filamentous cyanobacteria. 
436 Etymology. The given species name is an adjective derived from the Greek word dendron that 437 refers to tree, and crevace from the old French word referring to groove (Brown 1956) which 438 denotes the presence of branching and meandering grooves along the surface of the sponge. We 439 use the feminine dendrocrevacea assuming that Neopetrosia is feminine, following Article 31.2 440 of the International Code for Zoological Nomenclature (http://www.iczn.org/, accessed on 441 October 1, 2018).

442

443 Neopetrosia cristata sp. nov.

444 (Fig. 4; Table 1)

445

Type material and type locality. Holotype: UF 3859, Panamá, Bocas del Toro, Dolphin Rock

447 $\left(9.35076^{\circ} \mathrm{N}, 82.1863^{\circ} \mathrm{W}\right), 14 \mathrm{~m}$ in depth, coll. Jan Vicente and Arcadio Castillo, May 20, 2015.

448

449

Description. The holotype is a thickly (up to $1 \mathrm{~cm}$ ) encrusting sponge with an irregular shape, 10

450

451 $\mathrm{cm}$ in diameter. Surface with scattered pointy conulose ends or smooth ridges. Oscules aligned on ridges along the sponge body, sometimes on top of conical elevations, $<1 \mathrm{~mm}$ in diameter.

452 There are also sometimes narrow grooves that converge around oscules (Fig. 4 A, arrow). Consistency is firm but crumbly when torn. Surface texture is smooth and velvety. Specimens exude a sticky substance when squeezed in situ. External color is reddish brown to dark purple and the interior is light-yellow. Interior and exterior tissues turned to a light-yellow color in 456 ethanol.

457

Skeleton. The ectosome is composed of a rather confused reticulation of loose multispicular tracts, 3-15 spicules and 40-120 $\mu \mathrm{m}$ across, forming circular to polygonal meshes, $150-250 \mu \mathrm{m}$ in diameter (Fig. 4 B). Cyanobacterial pigments penetrate to $700 \mu \mathrm{m}$ inside the choanosome (Fig. $4 \mathrm{C})$. The choanosome consists of a confused reticulation of loose multispicular tracts, 5-20 spicules and 60-100 $\mu \mathrm{m}$ across (Fig. $4 \mathrm{D}$ ), forming circular meshes, $100-150 \mu \mathrm{m}$ in diameter (Fig. 3 E).

466

467

468

469

470

471

472

473

Spicules. Slightly curved oxeas, $121-160 \times 2.1-9.6 \mu \mathrm{m}$ (Fig. 3 F; Table 1).

Habitat and ecology. The holotype was found in a spur and groove, high wave energy environment, growing on a dead coral skeleton.

\section{Distribution. Bocas del Toro, Panamá.}

474 dendrocrevacea sp. nov. than any other congeneric, with $98 \%$ identity, and diverged from $N$.

475 proxima with strong bootstrap support (Fig. 1A). Additional sequence data spanning the COI I3- 
476 M11 extension (700 bp product alignment) showed that $N$. dendrocrevacea sp. nov. and $N$.

477 cristata sp. nov. were $96 \%$ identical which further supports their heterospecificity. This species

478 shares many external morphological characters with $N$. dendrocrevacea sp. nov. These

479 characters are 1) the appearance of grooves along the sponge's surface that converge at the 480 oscules, 2) the velvety texture of the sponge surface, and 3) the disorganized reticulation of the 481 choanosome and ectosome. Nevertheless, both of these species are distinguishable based on the 482 morphology of the grooves along the surface of the sponge which are a lot less pronounced and 483 fewer in number in N. cristata sp. nov. (Fig. 4 A). In N. dendrocrevacea sp. nov. up to 7 grooves

484

485

486

487

488

489

490

491

492

493

494

495

496

497

498

499

500

501

502

503

504

505

506

507

508

509

510

511

512

513

514

515 converge around the oscules in both branching (Fig. 3 B) and encrusting (Fig. 3 A and 3 C) individuals, forming a star-like pattern around the oscules. The appearance of a crown or irregular mounds around the oscules is also missing in N. cristata sp. nov. The diameter of the oscules is $<1 \mathrm{~mm}$ in $N$. cristata $\mathbf{s p}$. nov., being larger than $1 \mathrm{~mm}$ in $N$. dendrocrevacea $\mathbf{s p . ~ n o v . ~}$ The surface of $N$. cristata sp. nov. is also smoother and lacks the rounded knobs surrounded by grooves found in $N$. dendrocrevacea sp. nov., while those are pointed and dispersed in $N$. cristata sp. nov. Spicules in Panamá are also somewhat smaller and straighter in N. cristata sp. nov. [holotype UF 3859: 121-142.1 ( \pm 9.8$)-163.2]$ than in $N$. dendrocrevacea sp. nov. [PPA 07: 111-156.5 ( \pm 14.6$)-181$; holotype UF 3854: 91-165.2 ( \pm 15.9$)-188]$.

Etymology. The given species name is an adjective derived from the Latin word crista, referring to the surface ridges of the holotype (Brown 1956). We use the feminine cristata, assuming that Neopetrosia is feminine, following Article 31.2 of the International Code for Zoological Nomenclature (http://www.iczn.org/, accessed on October 1, 2018).

\section{Neopetrosia sigmafera sp. nov.}

\section{(Fig. 5, Fig. S3; Table 1, Table 2)}

Type material and type locality. Holotype: UF 3857, Bocas del Toro, Panamá, Punta Caracol $\left(9.3777^{\circ} \mathrm{N}, 82.1863^{\circ} \mathrm{W}\right), 3 \mathrm{~m}$ in depth, coll. Jan Vicente, May 8, 2015. Paratypes: Cartagena, Colombia: ICN-MHN(Po) 270, Islas del Rosario, Pajarales, close to Yohmara islet $\left(10.1779^{\circ} \mathrm{N}\right.$, $\left.75.7750^{\circ} \mathrm{W}\right), 5 \mathrm{~m}$ in depth, coll. Sven Zea, March 10, 2002. INV POR1338, 1339, Isla del del Rosario, Pajarales (lagoon) $\left(10.1780^{\circ} \mathrm{N}, 75.7750^{\circ} \mathrm{W}\right), 4-5 \mathrm{~m}$ in depth coll. Sven Zea, August $13,2014$.

Additional material. Bocas del Toro, Panamá: uncatalogued samples PPA 36, Isla Colón, Aeropuerto $\left(9.3339^{\circ} \mathrm{N}, 82.2548^{\circ} \mathrm{W}\right), 7 \mathrm{~m}$ in depth, coll. Sven Zea, August 9, 2012; PPA 48, Isla Cristobal, Buoy 19 (9.3018 $\left.\mathrm{N}, 82.2943^{\circ} \mathrm{W}\right), 8 \mathrm{~m}$ in depth, coll. Sven Zea, August 15, 2012.

12 Martinique: uncatalogued samples SZ-20, SZ-21, Les Anses d'Arlet, Le Grande Anse, Salomon's Garden, Northeast point $\left(14.5053^{\circ} \mathrm{N}, 61.0947^{\circ} \mathrm{W}\right), 11-18 \mathrm{~m}$, coll. Sven Zea, December 5, 2013. Uncatalogued fragment SZ-23, Les Anses d'Arlet, Le Grande Anse, Pointe Legarde, Southeast point $\left(14.4969^{\circ} \mathrm{N} ; 65.0897^{\circ} \mathrm{W}\right), 24 \mathrm{~m}$, coll. Sven Zea, December, 2013. 
517 Description. Group of tubes or chimneys or ramified, erect, anastomosed mounds, reaching 10-

$51830 \mathrm{~cm}$ in width and 10-30 cm in height (Fig. $5 \mathrm{~A}, \mathrm{~B}, \mathrm{C}$ ). Sponge surface is smooth, but

519 sometimes with horizontal crests (sinuous channels) (Fig. 5 C). Surface is also quite porous (0.5-

$5201 \mathrm{~mm}$ diameter pores) and in some specimens can be reticulated. Oscules are generally apical

521 and measure $2-5 \mathrm{~mm}$ in some individuals (Fig. $5 \mathrm{~A}$ ) and up to a $1-2 \mathrm{~cm}$ in others (Fig. $5 \mathrm{C}$ ). A

522 translucent membrane surrounding the oscules was obvious in some individuals. Consistency is

523 firm, rigid and tough to cut with scalpel but brittle once squeezed with considerable force. Unlike

524 the other congeneric species described in this study, the sponge did not exude a sticky substance

525 when squeezed in situ. The exterior color varies between brownish amber, yellow with sporadic

526 brownish-green blotches (Fig. 5 A), to crimson with light and dark tones (Fig. 5 C). Color at the

527 base and in the interior of the sponge is light-yellow.

528

529

Skeleton. The ectosome is partially tangential, isodictyal, with unispicular or paucispicular tracts

530

531 (1-6 spicules and 13-75 $\mu \mathrm{m}$ across) (Fig. 5 E, 5 F; Fig. S3 A-C). Spongin was detected in some nodal points in the ectosome where ascending choanosomal tracts connect with perpendicular

532 spicules along the ectosome (Fig. 5 E; Fig. S3 A). Pigments from cyanobacteria penetrate about

533 $1 \mathrm{~mm}$ into the choanosome (Fig. $5 \mathrm{H}$, I; Fig. S3 D). The choanosome is an anisotropic

534 reticulation with ascending multispicular tracts (4-8 spicules and 1-80 $\mu \mathrm{m}$ across) and

535 occasional 130-250 $\mu \mathrm{m}$ openings, interconnected by single or loosely arranged spicules (Fig. 5 H, I; Fig. S3 G-I). The choanosomal tracts have a larger number of free spicules, are thicker,

537 more confused, and become harder to depict deeper into the choanosome. Tracts become thinner as they ascend towards the ectosome, eventually becoming almost unispicular. Channels in the choanosome have a diameter $0.3-2 \mathrm{~mm}$.

540

541 Spicules. Slightly curved oxeas, hastate, with conical to sharp ends, 130-260 × 5-18 $\mu \mathrm{m}$ (Table

542 1). The mean of oxea sizes vary according to the location where specimens were collected (Fig. 5

$543 \mathrm{~J}-\mathrm{L})$. C-shaped sigmas are present in the ectosome and choanosome, 8-21-33 $\mu \mathrm{m}$ in length,

544 showing no variation in size among geographic locations but varied abundance across specimens 545 (Table 2).

546

547 Habitat and ecology. This species is found on shallow patch reefs and sand flats $(3 \mathrm{~m})$ in Bocas

548 del Toro and Islas del Rosario (Cartagena), and deeper reef habitats in Martinique (11-24 m).

549 This species is viviparous, being the only congener observed to brood larvae in the summer 550 months in Bocas del Toro, Panamá (Fig. 5 G). A detailed description of the morphology and 551 phototactic swimming behavior of Neopetrosia sigmafera sp. nov. larvae are described by Collin 552 et al. (2010). At the time, $N$. sigmafera sp. nov. was misidentified as $N$. proxima, but the morphological assessment in this study clearly shows a different spicule composition, and 554 skeletal arrangement of the choanosome and ectosome from $N$. proxima. The presence of larvae 555 seems to be a diagnostic character that also helps distinguish it from $N$. proxima when both are 
556 found living in the same habitat. Zoanthids are occasionally found growing on $N$. sigmafera sp. 557 nov. but not on N. proxima in shallow reef habitats of Bocas del Toro (Fig. $5 \mathrm{D}$ ). This sponge is 558 known to harbor a host specific community of the cyanobacteria species Synechococcus 559 spongiarum which produce high amounts of chlorophyll-a (Erwin \& Thacker 2007, 2008).

560

561 Distribution. Panamá (Bocas del Toro), Colombia (Cartagena), Martinique (Les Anses d' Arlet).

562

563

564

565 S. Zea observed specimens in Belize (Carrie Bow Cay and Pelican Cays).

566

567

568

569

570

571

572

573

574

575

576

577

578

579

580

581

582

583

584

585

586

587

588

589

590

591

592

593

594

Taxonomic remarks. Similar in situ characters shared between Neopetrosia sigmafera $\mathbf{s p . ~ n o v . ~}$ and Neopetrosia proxima have made their classification difficult over the last decade; particularly in Bocas del Toro, Panamá, where they are sympatric (Fig. 5 A and $2 \mathrm{~A}$ respectively). Nevertheless, the phylogenetic analysis of both nuclear and mitochondrial sequence data placed $N$. sigmafera sp. nov. in a well-supported and deeply divergent clade $(<85$ $\%$ sequence similarity) from all other new congeners and $N$. proxima (Fig. 1). These results were further supported by several morphological differences. For example, a closer look at the spicules of each species revealed that oxeas are longer, thicker, and have more hastate endings in $N$. sigmafera sp. nov. $(130-260 \times 5-18 \mu \mathrm{m})$ compared to $N$. proxima $(85-223 \times 2.4-10 \mu \mathrm{m})$. Neopetrosia sigmafera $\mathbf{s p . ~ n o v . ~ a l s o ~ h a s ~ s i g m a s ~ a s ~ m i c r o s c l e r e s , ~ w h i c h ~ a r e ~ n e v e r ~ p r e s e n t ~ i n ~} N$. proxima or any other Neopetrosia spp. The skeleton is also less dense, with less massive spicule tracts in N. sigmafera sp. nov. Oxeas are also smaller and thinner than observed in Neopetrosia dendrocrevacea sp. nov. and Neopetrosia cristata sp. nov. Grooves, which are a diagnostic character of $N$. dendrocrevacea sp. nov. are also absent in $N$. sigmafera sp. nov. From all congeners, larvae were only found in $N$. sigmafera sp. nov., suggesting that viviparity seems to be a diagnostic character of this species.

The external morphology of this species is also similar to Neopetrosia dominicana (PulitzerFinali 1986), but the ladder has strongyles instead of oxeas, and also lacks sigmas. There are also some similarities with Xestospongia caminata (Pulitzer-Finali 1986), although the oscules are much larger $(5-10 \mathrm{~mm})$ and spicules are larger $(200-260 \times 5-14 \mu \mathrm{m})$ in the latter species. In addition to oxeas, the spicule composition of $X$. caminata also includes strongyles, while sigmas are absent. Additionally, although $N$. sigmafera sp. nov. also shares a similar branching morphology with Neopetrosia subtriangularis (Duchassaing \& Michelotti 1864), the skeleton of $N$. subtriangularis is much more neatly reticulated with numerous circular channels, denser multispicular tracts, and smaller oxeas (131-181 × 1.6-11.7 $\mu \mathrm{m})$. Xestospongia bocatorensis (Diaz et al. 2007) also has hastate oxeas and sigmas, but oxeas reach greater lengths (230-320 $\times$ 8-15 $\mu \mathrm{m}$ ), and sigmas have a smaller length range (10-26 vs. 8-33 $\mu \mathrm{m}$ in $N$. sigmafera $\mathbf{s p .}$ nov.). In addition, $X$. bocatorensis is a thinly encrusting sponge with a purple signature color from associated Oscillatoria filamentous cyanobacteria dispersed throughout the ectosome and choanosome (Diaz et al. 2007). In contrast, color patterns in N. sigmafera sp. nov. are similar to 
595

596

597

598

599

600

601

602

603

604

605

606

607

608

609

610

611

612

613

614

615

616

617

618

619

620

621

622

623

624

625

626

627

628

629

630

631

632

633

634

other congeners, having two distinct colors across the body, brown ectosome from cyanobacteria and light-yellow choanosome.

Etymology. The given species name is an adjective that combines the name of the sigma microsclere with the Greek suffix phero, which translates to "carrying" or "bearing" (Brown, 1956). We use the feminine sigmafera, assuming that Neopetrosia is feminine, following Article 31.2 of the International Code for Zoological Nomenclature (http://www.iczn.org/, accessed on October 1, 2018).

\section{Discussion}

Molecular and morphological assessments of putative Neopetrosia proxima and close relatives sampled from Martinique, and the Southern Caribbean, revealed three new species with a variety of new morphological characters, and a new reproductive strategy for the genus. Differences in morphological characters were mostly resolved by partial sequences of the mitochondrial (COI) gene but less so by nuclear genes (28S rRNA and $18 \mathrm{~S}$ rRNA). Neopetrosia is defined by having the presence of a hispid surface produced by the rise of subectosomal tracts above a compact choanosomal skeleton composed of circular meshes with anisotropic reticulation of oxeas that are $<200 \mu \mathrm{m}$ in length (Desqueyroux-Faúndez \& Valentine 2002). These characters were well supported by COI, 28S and 18S rRNA sequences in three variable paratypes of $N$. proxima which were $100 \%$ identical. Identical sequences across the three $N$. proxima paratypes support plasticity of morphological variations in color, oscula alignment, the size of circular meshes throughout the choanosome and ectosome, and the thickness of spicule tracts. In a closer examination of the new congeners we have found that $N$. dendrocrevacea sp. nov. and $N$. cristata sp. nov. have a more confused ectosomal and choanosomal skeleton, with less obvious circular meshes. These morphological differences were supported by a 4-5\% divergence in COI sequences of $N$. cristata sp. nov. and $N$. dendrocrevacea sp. nov. to $N$. proxima. The recently discovered congener from mesophotic reefs in Curacao, $N$. ovata, also shows a similar confused skeleton organization as $N$. dendrocrevacea sp. nov. and $N$. cristata sp. nov. (Van Soest et al. 2014). In addition, $N$. sigmafera sp. nov. further deviates from this definition by the presence of sigmas (microscleres), oxeas $>200 \mu \mathrm{m}$ in length, and being the only congener so far known to brood larvae. Neopetrosia sigmafera sp. nov. was also the most distantly related congener to $N$. proxima based on mitochondrial and nuclear sequences $(<85 \%$ sequence identity).

Improved resolution of the COI gene over nuclear genes are in agreement with the phylogeny of other Haplosclerida where mitochondrial genes (including the COI I3-M11 extension) resolved up to 12 well supported subclades of Haliclona spp., while ribosomal sequences only resolve six (Knapp et al. 2015). Similar results were also observed in Tethya spp. where mitochondrial genes resolved up to five supported subclades, while ribosomal sequences supported four (Schaffer et al. 2018). In all phylogenetic trees, N. proxima, $N$. 
635 dendrocrevacea $\mathbf{s p .}$ nov. and $N$. cristata sp. nov. formed a well supported clade with deep 636 divergence from $N$. sigmafera sp. nov. These results are congruent with multiple diagnostic 637 morphological characters present in N. sigmafera sp. nov. that are absent in all other congeners 638 (i.e. presence of sigmas and brooding larvae).

639 Despite these striking differences, and distant genetic relatedness to other congeners, it is 640 difficult to place $N$. sigmafera $\mathbf{~ s p . ~ n o v . ~ i n ~ a ~ d i f f e r e n t ~ g e n u s ~ o n ~ t h e ~ b a s i s ~ o f ~ i t s ~ v i v i p a r o u s ~ n a t u r e ~}$ 641 or presence of sigmas. Other than Xestospongia bocatorensis, N. sigmafera sp. nov. is the only

642 other larval brooding Petrosiidae (Collin et al. 2010), which rejects the hypothesis that all

643 Petrosiidae are oviparous (Fromont \& Bergquist 1994; Maldonado \& Riesgo 2009), and shows

644 that viviparity is not a good synapomorphic character (Van Soest \& Hooper 2002). In addition, 645 the only other Petrosiidae with sigmas is also X. bocatorensis (Diaz et al. 2007), which shows

646 that sigmas can be shared across different genera within Petrosiidae. Although being closely 647 related to the genus Gelliodes based on mitochondrial and nuclear markers, N. sigmafera $\mathbf{s p .}$

648 nov. shares no morphological characters with this genus other than the presence of sigmas and 649 oxeas.

650 Shared morphological characters between N. sigmafera sp. nov. and

651 other Neopetrosia, are the pauci- to multispicular ascending and interconnecting tracts, often

652 ending in spicule brushes which support, when present, a tangential uni- to paucispicular

653 reticulation. The firm consistency, the presence of brown- purple pigments in the ectosome with

654 a light-yellow-colored interior, plus the overall size of the spicules are all characters that support

655 a generic morphological classification for $N$. sigmafera sp. nov. within Neopetrosia. The

656 presence of sigmoid microscleres is generally not a diagnostic character at the generic level in

657 this family or other Haplosclerid families, and together with viviparity, they are not

658 monophyletic across different taxa by mitochondrial or ribosomal molecular markers

659 (Redmond et al. 2011). Thus, given the current lack of congruence between morphological and

660 molecular classifications of Haplosclerida, we are hesitant to erect a new genus for $N$. sigmafera

661 sp. nov. Its placement should be considered temporary while more suitable molecular markers

662 showing monophyly for its unique characters are discovered.

663 Our study also highlights the effect that environmental factors may have on the size of

664 oxeas. Previous studies have shown that spicule morphology can be influenced by

665 hypersilicification as a result of high silica concentrations (Maldonado et al. 1999). Sponges can

666 also produce smaller spicules by living in association with other sponges (Vicente et al. 2014). In

667 this study, higher silica concentrations from terrestrial runoff in habitats closer to the continental

668 shelfs are likely the cause of larger oxeas in both $N$. dendrocrevacea sp. nov. and N. sigmafera

669 sp. nov. collected in Bocas del Toro, Urabá, Cartagena and Santa Marta (continental shelf), than

670 in specimens collected in San Andres or Martinique (oceanic islands). Similar variations in

671 spicule sizes have been reported for other species collected in sites with low/high terrestrial

672 runoff (Zea 1987, Debiasse \& Hellberg 2015, Vicente et al. 2016, Silva \& Zea 2017).

673 Despite highlighting the polyphyletic nature of Haplosclerida, applying a multi-locus

674 based approach using ribosomal and mitochondrial markers continues to prove as a useful tool in 
675 resolving the taxonomy between congeneric species. Recently this approach has been used 676 across a wide taxonomic range of sponges (Erpenbeck et al. 2016; Yang et al. 2017). These 677 methods are useful as a first pass assessment of classification for a wide range diversity of 678 sponges, to be subsequently integrated with morphological systematics. However, in order to 679 understand the evolutionary relationship within Haplosclerida we must continue to focus our 680 research efforts towards finding monophyletic markers by sequencing more genomes from 681 species within different families of Haplosclerida.

682

\section{Conclusions}

684 We report molecular and morphological congruence of three new Neopetrosia spp. in the 685 Caribbean. Molecular congruence was mostly revealed at the highest resolution by partial 686 sequences of the mitochondrial cytochrome oxidase subunit 1 (COI) and less by nuclear ones

688

689 (18S rRNA and 28S rRNA). The most distantly related new congener based on partial COI sequences was $N$. sigmafera sp. nov., which adds the presence of sigma microscleres, significantly wider/longer oxeas $(>200 \mu \mathrm{m})$, and the presence of parenchymella larvae to the genus. Neopetrosia dendrocrevacea sp. nov. and $N$. cristata sp. nov. were confirmed as sister species based on partial COI sequences and by the shared appearance of a more confused skeletal arrangement, and the presence of grooves on the surface of the sponge body converging to its oscula. Differences in morphological characters from $N$. proxima were also confirmed by differences in COI sequences. Despite being a polyphyletic genetic fragment in Neopetrosia spp., our study shows that the partial COI gene fragment continues to be a useful marker in resolving cryptic species belonging to highly diverse orders with variable growth forms.

697

698

699

700

701

702

703

\section{4}

705

706

707

708

709

710

711

\section{Acknowledgements}

We thank Cristina Díaz and Robert W. Thacker for providing helpful discussion points on the taxonomy of Neopetrosia spp. We are indebted to Rachel Collin and Plinio Gondola for hosting J.V. at the Bocas del Toro STRI research station. Arcadio Castillo and Micah J. Marty, are thanked for SCUBA diving assistance. We thank Laszlo Takacs at the NanoImaging Facility, University of Maryland Baltimore, and Inga Conti-Jerpe at the University of North Carolina Wilmington, for help with SEM images. This is HIMB contribution Nr. XXX, SOEST contribution Nr. XXX, CECIMAR contribution Nr. XXX and INVEMAR contribution Nr. XXX. 


\section{References}

715 Abràmofff, M.D., Magalhães, P.J. \& Ram, S.J. (2005) Image processing with ImageJ Part II.

716 Biophotonics International, 11, 36-43.

717 Altschul, S.F., Gish, W., Miller, W., Myers, E.W. \& Lipman, D.J. (1990) Basic local alignment

718 search tool. Journal of Molecular Biology, 215, 403-410.

719 Alvarez, B., van Soest, R.W.M. \& Rützler, K. (2002) Svenzea, a new genus of Dictyonellidae

720 (Porifera: Demospongiae) from the tropical reef environments, with description of two new

721 species. Contributions to Zoology, 71 (4), 171-176.

722 Borchiellini, C., Chombard, C., Manuel, M., Alivon, E., Vacelet, J. \& Boury-Esnault, N. (2004)

723 Molecular phylogeny of Demospongiae: Implications for classification and scenarios of

724 character evolution. Molecular Phylogenetics and Evolution, 32, 823-837.

725 Bickford, D., Lohman, D.J., Sodhi, N.S., Ng, P.K., Meier, R., Winker, K., Ingram, K.K. and Das,

726 I., 2007. Cryptic species as a window on diversity and conservation. Trends in ecology \&

727 evolution, $22(3)$, pp.148-155.

728 Brown, R.W. (1956) Composition of scientific words. A manual of methods and lexicon of

729 materials for the practice of logotechnics, revised edition. Smithsonian Institution Press,

730 Washington, D.C., 882 pp.

731 Campos, M., Mothes, B., Eckert, R. \& Van Soest, R.W.M. (2005) Haplosclerida (Porifera:

732 Demospongiae) from the coast of Maranhão State, Brazil, Southwestern Atlantic. Zootaxa, 963,

733 1-22.

734 Carballo, J.L., Aguilar-Camacho, J.M., Knapp, I.S. \& Bell, J.J. (2013) Wide distributional range

735 of marine sponges along the Pacific Ocean. Marine Biology Research, 9 (8), 768 - 775.

736 Cárdenas, P., Pérez, T. \& Boury-Esnault, N. (2012) Sponge Systematics Facing New Challenges.

737 Advances in Marine Biology 61, 79-209.

738 Chombard, C., Boury-Esnault, N. \& Tillier, S. (1998) Reassessment of Homology of

739 Morphological Characters in Tetractinellid Sponges Based on Molecular Data. Systematic

740 Biology, 47 (3), 351-66.

741 Collin, R., Díaz, M.C., Norenburg, J., Rocha, R.M., Sánchez, J.A., Schulze, A., Schwartz, M. \&

742 Valdés, A. (2005) Photographic Identification Guide to Some Common Marine Invertebrates of

743 Bocas Del Toro, Panamá. Caribbean Journal of Science, 41 (3), 638-707,

744 Collin, R., Mobley, A.S., Lopez, L.B., Leys, S.P., Diaz, M.C. \& Thacker, R.W. (2010)

745 Phototactic responses of larvae from the marine sponges Neopetrosia proxima and Xestospongia

746 bocatorensis (Haplosclerida: Petrosiidae). Invertebrate Biology, 129, 121-128.

747 Concepcion, G.T., Crepeau, M.W., Wagner, D., Kahng, S.E. and Toonen, R.J., 2008. An

748 alternative to ITS, a hypervariable, single-copy nuclear intron in corals, and its use in detecting

749 cryptic species within the octocoral genus Carijoa. Coral Reefs, 27 (2), pp.323-336.

750 Debiasse, M.B. \& Hellberg, M.E. (2015) Discordance between morphological and molecular

751 species boundaries among Caribbean species of the reef sponge Callyspongia. Ecology and

752 Evolution, 5 (3), 663-75. 
753 Desqueyroux-Faúndez, R. \& Valentine, C. (2002) Family Petrosiidae Van Soest, 1980. In:

754 Hooper, J.N.A. \& van Soest R.W.M. (Eds), Systema Porifera: a guide to the classification of

755 sponges. Kluwer Academic/Plenum Publishers, New York, 906-917.

756 Díaz, M.C. (2005) Common sponges from shallow marine habitats from Bocas del Toro region,

757 Panamá. Caribbean Journal of Science, 41, 465-475.

758 Díaz, M.C., Thacker, R.W., Rützler, K., Piantoni, C. (2007) Two new haplosclerid sponges from

759 Caribbean Panamá with symbiotic filamentous cyanobacteria, and an overview of sponge-

760 cyanobacteria associations. In: Custódio, M.R., Lôbo-Hajdu, G., Hajdu, E. \& Muricy, G. (Eds.),

761 Porifera Research. Biodiversity, Innovation and Sustainability. Livros de Museu Nacional 28,

762 Rio de Janeiro, pp. 31-39.

763 Duchassaing de Fonbressin, P. (1850) Animaux radiaires des Antilles. Plon Frères, Paris, 35 pp.

764 Duchassaing de Fonbressin, P. \& Michelotti, G. (1864) Spongiaires de la mer Caraibe.

765 Natuurkundige verhandelingen van de Hollandsche maatschappij der wetenschappen te

766 Haarlem, 21, 1-124.

767 Erpenbeck, D., Duran, S., Rützler, K., Paul, V., Hooper, J.N.A. \& Wörheide, G. (2007) Towards

768 a DNA taxonomy of Caribbean demosponges: A gene tree reconstructed from partial

769 mitochondrial $\mathrm{CO} 1$ gene sequences supports previous rDNA phylogenies and provides a new

770 perspective on the systematics of Demospongiae. Journal of the Marine Biological Association

771 of the United Kingdom, 87 (6), 1563-1570.

772 Erpenbeck, D., Voigt, O., Al-Aidaroos, A.M., Berumen, M.L., Büttner, G., Catania, D.,

773 Guirguis, A.N., Paulay, G., Schätzle, S. \& Wörheide, G. (2016) Molecular biodiversity of Red

774 Sea demosponges. Marine Pollution Bulletin, 105 (2), 507-514.

775 Erwin, P.M. \& Thacker, R.W. (2007) Incidence and identity of photosynthetic symbionts in

776 Caribbean coral reef sponge assemblages. Journal of the Marine Biological Association of the

777 United Kingdom, 87 (6), 1683-1692.

778 Erwin, P.M. \& Thacker, R.W. (2008) Cryptic diversity of the symbiotic cyanobacterium

779 Synechococcus spongiarum among sponge hosts. Molecular Ecology, 17 (12), 2937-2947.

780 Folmer, O., Black, M., Hoeh, W., Lutz, R. \& Vrijenhoek, R. (1994) DNA primers for

781 amplification of mitochondrial cytochrome c oxidase subunit I from diverse metazoan

782 invertebrates. Molecular Marine Biology and Biotechnology, 3 (5), 294-299.

783 Fromont, J. \& Bergquist, P.R. (1994) Reproductive biology of three sponge species of the genus

784 Xestospongia (Porifera: Demospongiae: Petrosida) from the Great Barrier Reef. Coral Reefs, 13,

$785 \quad 119-126$.

786 Forsman, Z.H., Barshis, D.J., Hunter, C.L. and Toonen, R.J., 2009. Shape-shifting corals:

787 molecular markers show morphology is evolutionarily plastic in Porites. BMC evolutionary

788 biology, $9(1)$, pp. 45.

789 Geller, J., Meyer, C., Parker, M. and Hawk, H. (2013) Redesign of PCR primers for

790 mitochondrial cytochrome $\mathrm{c}$ oxidase subunit I for marine invertebrates and application in all-taxa

791 biotic surveys. Molecular ecology resources, 13 (5), 851-861. 
792 Hentschel, E. (1912) Kiesel- und Hornschwämme der Aru- und Kei-Inseln. Abhandlungen

793 herausgegeben von der Senckenbergischen naturforschenden Gesellschaft, 34, $293-448$.

794 Holmes, B. \& Blanch, H. (2007) Genus-specific associations of marine sponges with group I

795 crenarchaeotes. Marine Biology, 150 (5), 759-772.

796 Hooper, J.N.A. (1984) A new genus and two new species of haplosclerid sponges (Porifera:

797 Demospongiae) from the Timor Sea, Northwest Australia. Proceedings of the Royal Society of

798 Victoria 96, 55-60.

799 Hooper, J.N.A. \& Van Soest, R.W.M. (2006) A new species of Amphimedon (Porifera, 800 Demospongiae, Haplosclerida, Niphatidae) from the Capricorn-Bunker Group of Islands, Great

801 Barrier Reef, Australia: Target species for the "sponge genome project." Zootaxa, 1314, 31-39.

802 Huelsenbeck, J.P. \& Ronquist, F. (2001) MRBAYES: Bayesian inference of phylogenetic trees.

803 Bioinformatics, 17, 754-755.

804 Kayal, E. \& Lavrov, D. V. (2008) The mitochondrial genome of Hydra oligactis (Cnidaria,

805 Hydrozoa) sheds new light on animal mtDNA evolution and cnidarian phylogeny. Gene, 410 (1), $806 \quad 177-186$.

807 Kearse, M., Moir, R., Wilson, A., Stones-Havas, S., Cheung, M., Sturrock, S., Buxton, S., 808 Cooper, A., Markowitz, S., Duran, C., Thierer, T., Ashton, B., Meintjes, P. \& Drummond, A.

809 (2012) Geneious Basic: An integrated and extendable desktop software platform for the 810 organization and analysis of sequence data. Bioinformatics, 28, 1647-1649.

811 Kelly-Borges, M. \& Pomponi, S.A. (1994) Phylogeny and classification of lithistid sponges

812 (Porifera: Demospongiae): a preliminary assessment using ribosomal DNA sequence

813 comparisons. Molecular Marine Biology and Biotechnology, 3, 87-103.

814 Kirkpatrick, R. (1900) On the Sponges of Christmas Island. Proceedings of the Zoological

815 Society of London, 127-141.

816 Knapp, I.S., Forsman, Z.H., Williams, G.J., Toonen, R.J. \& Bell, J.J. (2015) Cryptic species

817 obscure introduction pathway of the blue Caribbean sponge (Haliclona ( Soestella ) caerulea),

818 (order: Haplosclerida) to Palmyra Atoll, Central Pacific. PeerJ, 3, e1170.

819 Kumar, S., Stecher, G. \& Tamura, K. (2016) MEGA7: Molecular Evolutionary Genetics

820 Analysis Version 7.0 for Bigger Datasets. Molecular Biology and Evolution, 33, 1870-1874.

821 Lamarck, J. (1814) Sur les polypiers empâtés. Suite du mémoire intitulé: Sur les polypiers

822 empâtés. Suite des éponges. Annales du Muséum national d'histoire naturelle Paris, 20, 294

823312.

824 De Laubenfels, M.W. (1932) The marine and fresh-water sponges of California. Proceedings of

825 the United States National Museum, 81, 1-140.

826 De Laubenfels, M.W. (1934) New sponges from the Puerto Rican deep. Smithsonian

827 Miscellaneous Collections, 91, 1-28.

828 De Laubenfels, M.W. (1949) Sponges of the western Bahamas. American Museum Novitates,

$8291431,1-25$.

830 De Laubenfels, M.W. (1954) The sponges of the West-Central Pacific. Oregon State

831 Monographs. Studies in Zoology, 7, 1-306. 
832 Lavrov, D. V., Wang, X. \& Kelly, M. (2008) Reconstructing ordinal relationships in the 833 Demospongiae using mitochondrial genomic data. Molecular Phylogenetics and Evolution, 49 834 (1), 111-124.

835 Lehnert, H. \& Van Soest, R.W.M. (1996) North Jamaican Deep Fore-reef Sponges. Beaufortia, $83646,53-81$.

837 Lehnert, H. \& Van Soest, R.W.M. (1999) More North Jamaican deep fore-reef sponges.

838 Beaufortia, 49, 141-169.

839 Maldonado, M., Carmona, M.C., Uriz, M.J. \& Cruzado, A. (1999) Decline in Mesozoic reef-

840 building sponges explained by silicon limitation. Nature, 401, 785-788.

841 Maldonado, M. \& Riesgo, A. (2009) Gametogenesis, embryogenesis, and larval features of the 842 oviparous sponge Petrosia ficiformis (Haplosclerida, Demospongiae). Marine Biology, 156 (10), 843 2181-2197.

844 Morrow, C. \& Cárdenas, P. (2015) Proposal for a revised classification of the Demospongiae 845 (Porifera). Frontiers in Zoology, 12 (1), 7 pp.

846 Muricy, G., Lopez, D.A., Hajdu, E., Carvalho, M.S., Morae, F.C., Klautau, M., Menegola, C. \&

847 Pinheiro, U. (2011) Catalogue of Brazilian Porifera. Museu Nacional, Río de Janeiro, Serie

848 Livros, 46, 299 pp.

849 Pérez, T., Díaz, M.C., Ruiz, C., Cóndor-Luján, B., Klautau, M., Hajdu, E., Lobo-Hajdu, G., Zea, 850 S., Pomponi, S.A., Thacker, R.W., Carteron, S., Tollu, G., Pouget-Cuvelier, A., Thélamon, P., 851 Marechal, J.P., Thomas, O.P., Ereskovsky, A. V., Vacelet, J. \& Boury-Esnault, N. (2017) How a 852 collaborative integrated taxonomic effort has trained new spongiologists and improved 853 knowledge of Martinique Island (French Antilles, eastern Caribbean Sea) marine biodiversity. 854 PLoS ONE, 12 (3), e0173859.

855 Pulitzer-Finali (1986) A collection of West Indian Demospongiae (Porifera). In appendix, a list 856 of the Demospongiae hitherto recorded from the West Indies. Annali del Museo civico di storia 857 naturale Giacomo Doria, 86, 154-158.

858 Redmond, N.E., Morrow, C.C., Thacker, R.W., Diaz, M.C., Boury-Esnault, N., Cárdenas, P., 859 Hajdu, E., Lôbo-Hajdu, G., Picton, B.E., Pomponi, S.A., Kayal, E. \& Collins, A.G. (2013)

860 Phylogeny and systematics of demospongiae in light of new small-subunit ribosomal DNA (18S) 861 sequences. In: Integrative and Comparative Biology, 53 (3), 388-415.

862 Redmond, N.E., Raleigh, J., Van Soest, R.W.M., Kelly, M., Travers, S.A.A., Bradshaw, B., 863 Vartia, S., Stephens, K.M. \& McCormack, G.P. (2011) Phylogenetic relationships of the marine 864 Haplosclerida (Phylum Porifera) employing ribosomal (28s rRNA) and mitochondrial (COI, 865 nad1) gene sequence data. PLoS ONE, 6 (9), e24344.

866 Rützler, K., Diaz, M.C., Van Soest, R.W.M., Zea, S., Smith, K.P., Alvarez, B. \& Wulff, J. (2000)

867 Diversity of sponge fauna in mangrove ponds, Pelican Cays, Belize. Atoll Research Bulletin, 868 476, 229-248.

869 Santos, G.G., Sandes, J., Cabral, A. \& Pinheiro, U. (2016) Neopetrosia de Laubenfels, 1949 from 870 Brazil: Description of a new species and a review of records (Haplosclerida: Demospongiae:

871 Porifera). Zootaxa, 4114, 331-340. 
872 Schaffer, M.R., Dave, S.K. \& Bell, J.J. (2018) Hidden diversity in the genus Tethya: comparing

873 molecular and morphological techniques for species identification. Heredity, 1, doi:

874 10.1038/s41437-018-0134-6.

875 Setiawan, E. (2014) Genetic diversity of selected petrosiid sponges. Doctoral dissertation,

876 Ludwig-Maximillians University, Munich, 166 pp.

877 Setiawan, E., E. Erpenbeck, D., Wörheide, G., \& De Voogd, N. J. (2018). Bearing the wrong

878 identity: A case study of an Indo-Pacific common shallow water sponge of the genus

879 Neopetrosia (Haplosclerida; Petrosiidae). Zootaxa, 4500(1), 43-58.

880 Silva, J.A. \& Zea, S. (2017) New records of sponges of the genera Petrosia and Xestospongia

881 (Demospongiae: Haplosclerida: Petrosiidae) from the Colombian Caribbean. Boletín de

882 Investigaciones Marinas y Costeras-, 46, 113-136.

883 Sollas, W.J. (1885) A classification of the sponges. Annals and Magazine of Natural History,

884 Series 5, 16 (95), 395 pp.

885 Sperling, E.A., Peterson, K.J. \& Pisani, D. (2009) Phylogenetic-signal dissection of nuclear

886 housekeeping genes supports the paraphyly of sponges and the monophyly of eumetazoa.

887 Molecular Biology and Evolution, 26 (10), 2261-2274.

888 Stamatakis, A. (2006) RAxML-VI-HPC: Maximum likelihood-based phylogenetic analyses with 889 thousands of taxa and mixed models. Bioinformatics, 22, 2688-2690.

890 Stat, M., Baker, A.C., Bourne, D.G., Correa, A.M., Forsman, Z., Huggett, M.J., Pochon, X., 891 Skillings, D., Toonen, R.J., van Oppen, M.J. and Gates, R.D., 2012. Molecular delineation of 892 species in the coral holobiont. Advances in marine biology, 63, 1-65.

893 Thacker, R.W., Hill, A.L., Hill, M.S., Redmond, N.E., Collins, A.G., Morrow, C.C., Spicer, L., 894 Carmack, C.A., Zappe, M.E., Pohlmann, D., Hall, C., Diaz, M.C. \& Bangalore, P. V. (2013)

895 Nearly complete 28S rRNA gene sequences confirm new hypotheses of sponge evolution. In:

896 Integrative and Comparative Biology, 53 (3), 373-387.

897 Topsent, E. (1928) Spongiaires de l'Atlantique et de la Méditerranée provenant des croisières du

898 Prince Albert ler de Monaco. Résultats des campagnes scientifiques accomplies par le Prince

899 Albert I, Monaco. Imprimerie de Monaco, 74, 1-376.

900 Van Soest, R.W.M. (1980) Marine sponges from Curaçao and other Caribbean localities Part II.

901 Haplosclerida. Studies on the Fauna of Curaçao and Other Caribbean Islands, 62, 1-173.

902 Van Soest, R.W.M. (1984) Marine sponges from Curaçao and other Caribbean localities. Part III.

903 Poecilosclerida. Studies on the Fauna of Curaçao and other Caribbean Islands. 66 (199): 1-167.

904 Van Soest, R.W.M. (2017) Sponges of the Guyana Shelf. Zootaxa, 4217, 66 (199), 1-167.

905 Van Soest, R.W. M., Boury-Esnault, N., Hooper, J.N.A., Rützler, K., de Voogd, N.J., Alvarez de 906 Glasby, B., Hajdu, E., Pisera, A.B., Manconi, R., Schoenberg, C., Klautau, M., Picton, B., Kelly, 907 M., Vacelet, J., Dohrmann, M., Díaz, M.-C., Cárdenas, P. \& Carballo, J.L. (2018) World Porifera 908 database. Accessed at http://www.marinespecies.org/porifera on 2018-9-10.

909 Van Soest, R.W.M. \& Hooper, J.N.A. (2002) Suborder Petrosina Boury-Esnault \& Van Beveren, 910 1982. In: Hooper, J.N.A., Van Soest, R.W.M. \& P. Willenz (Eds.), Systema Porifera, Volume 1. 
911 Kluwer Academic/ Plenum Publishers, New York, Boston, Dordrecht, London, Moscow, pp. 912 891-892.

913 Van Soest, R.W.M., Meesters, E.H.W.G. \& Becking, L.E. (2014) Deep-water sponges (Porifera)

914 from Bonaire and Klein Curaçao, Southern Caribbean. Zootaxa, 3878 (5), 401-443

915 Van Soest, R.W.M. \& Stentoft, N. (1988) Barbados Deep-Water Sponges. In: Hummelinck, 916 P.W. \& Van der Steen, L.J. (Eds), Uitgaven van de Natuurwetenschappelijke Studiekring voor

917 Suriname en de Nederlandse Antillen. Studies on the Fauna of Curaçao and other Caribbean 918 Islands, 70, 1-175.

919 Van Soest, R.W.M., Stone, S.M., Boury-Esnault, N. \& Rützler, K. (1983) Catalogue of the

920 Duchassing \& Michelotti (1864) Collection of West Indian Sponges (Porifera). Bulletin

921 Zoologisch Museum, Universiteit van Amsterdam, 9, 189-205.

922 Vicente, J., Zea, S. \& Hill, R.T. (2016) Sponge epizoism in the Caribbean and the discovery of 923 new Plakortis and Haliclona species, and polymorphism of Xestospongia deweerdtae (Porifera).

924 Zootaxa, 4178 (2), 209-233.

925 Vicente, J., Zea, S., Powell, R.J., Pawlik, J.R. \& Hill, R.T. (2014) New epizooic symbioses

926 between sponges of the genera Plakortis and Xestospongia in cryptic habitats of the Caribbean.

927 Marine Biology 161 (12), 2803-2818.

928 Vosmaer, G.C.J. (1885) Porifera, Parts Vll-XI. In: H. G. Bronn (Ed.), Die Klassen und

929 Ordnungen des Thier-Reichs. 1. Leipzig \& Heidelberg, pp. 177-368, pls. XIX-XXV.

930 Wiedenmayer, F. (1977) Shallow-water sponges of the western Bahamas. Experientia.

931 Supplementum 28. Birkhäuser Verlag, Basel and Stuttgart, 1-287, pls. 1-43.

932 Wilson, H.V.P. (1925) Silicious and horny sponges collected by the US Fisheries steamer

933 "Albatross" during the Philippine Expedition. Bulletin of the United States National Museum, $934100(2,4), 273-532$.

935 Wörheide, G. and Erpenbeck, D., 2007. DNA taxonomy of sponges - progress and

936 perspectives. Journal of the Marine Biological Association of the United Kingdom, 87 (6), 1629-

9371633.

938 Yang, Q., Franco, C.M.M., Sorokin, S.J. \& Zhang, W. (2017) Development of a multilocus-

939 based approach for sponge (phylum Porifera) identification: Refinement and limitations.

940 Scientific Reports 7, 41422.

941 Zea, S. (1987) Esponjas del Caribe Colombiano. Catálogo Científico, Bogotá, 286 pp.

942 Zea, S. (2001) Patterns of sponge (Porifera, Demospongiae) distribution in remote, oceanic reef

943 complexes of the southwestern Caribbean. Revista de la Academia Colombiana de Ciencias

944 Exactas, Físicas y Naturales 25 (97), 579-592.

945 Zea, S., Henkel, T. \& Pawlik, J.R. (2014) The Sponge Guide: a picture guide to Caribbean

946 sponges. Available online at www.spongeguide.org (accessed 22-10-2018).

947 Zea, S. \& Rützler, K. (1983) A new species of Xestospongia (Porifera, Demospongea) from the

948 Colombian Caribbean. Caldasia, 817-831.

949

950 
Figure $\mathbf{1}$ (on next page)

Phylogenetic trees

Bayesian and Maximum Likelihood topology generated from partial sequences spanning the (A) Folmer (5') region of the cox1 gene, (B) D1-D2 region of the 28S rRNA gene and (C) 18S rRNA gene, from Haplosclerida taxa generated in this study (blue) and sequences downloaded from GenBank. Clades in panel C correspond to clades assigned by Redmond et al. (2013). Sequences in bold highlight other Neopetrosia species. Bootstrap values less than $50 \%$ have been omitted from the trees. Numerical values at nodes show Bayesian posterior probabilities followed by RAxML bootstrap values. Nodes with '--' refer to the absence of the node generated by RAXML. Type specimens are indicated by an asterisk at the end of the specimen's catalogue number. 
LN850179.1 Calyx arcuarius

66/-- [ KJ729034.1 Haliclona implexiformis

_ JX999082.1 Callyspongia siphonella JX999087. 1 Haliclona elegans JN242199.1 Haliclona oculata 1/91_ KX454496.1 Neopetrosia exigua

JN242193.1 Callyspongla 1/100 JN242194.1 Callyspongia ramosa

AJ843892. 1 Haliclona amphioxa

0.85/72 _ JN242213.1 Neopetrosia seriata

JN242219.1 Petrosia sp.

1/58 JN242217.1 Petrosia sp. E

$1 / 58$ J $92 / 83242220.1$ Petrosia sp. J

54/69 L JN242214.1 Petrosia sp. A

$0.97 / 72$
$0.99 / 89 L$ KX866751.1 Petrosia piciformis

$0.99 / 85$

J100 JN242218.1 Petrosia sp.

HQ452957.1 Xestospongia muta

$0.96 / 81 \_$JN242216.1 Petrosia sp. C

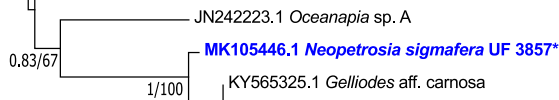

$1 /\left.100\right|_{\text {KY565325.1 Gelliodes aff. carnosa }} ^{\text {KY55327.1 }}$

stospongia dis

F519604.1 Cribrochalina vasculum

JN242215.1 Petrosia sp. B

EU237474.1 Amphimedon queenslandica

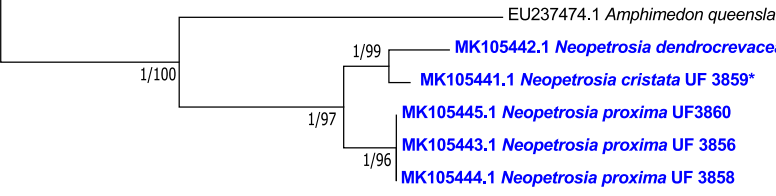

DAQ167168.1 Baikalospongia intermedia

\subsection{2 \\ (B) $28 \mathrm{~S}$ rRNA}

$\sqrt{1 / 86} \sqrt{1 / 100}\left[\begin{array}{l}\text { KC869457.1 Neopetrosia rosariensis } \\ \text { KC869499.1 Neopetrosia rosariensis }\end{array}\right.$ KC869497.1 Petrosia weinbergi

KC869533.1 Haliclona implexiformis

KC869463.1 Chalinula molitba

KC869599. 1 Haliclona manglaris

KC869461. 1 Haliclona tubifera

KC869487.1 Haliclona sp. n. P10x1

1/100 KC869516.1 Haliclona sp. n. P10x30

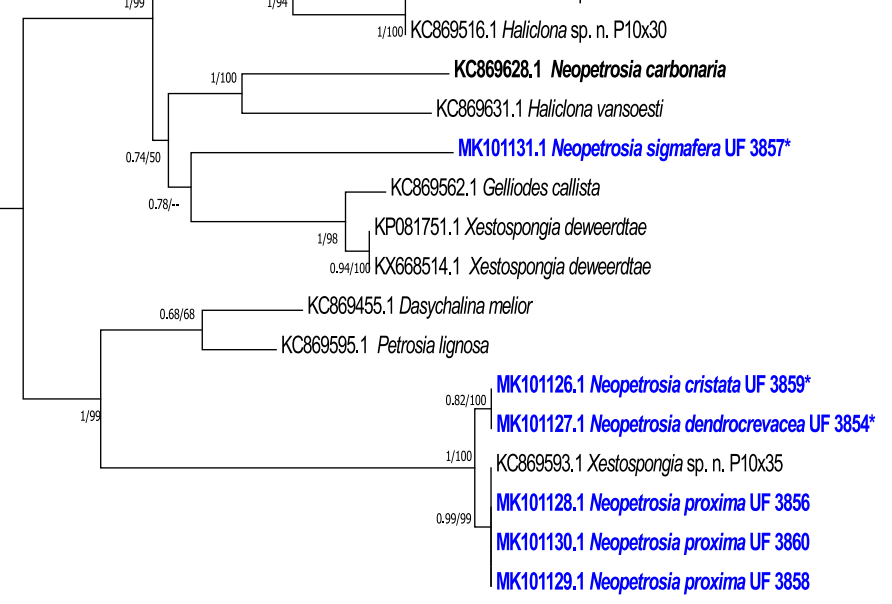

MK101129.1 Neopetrosia proxima UF 3858

26.1 Neopetrosia cristata UF $3859^{\circ}$

MK101127.1 Neopetrosia dendrocrevacea UF 3854*

Peer] reviewing PDF| (2018:10:32201:1:2:NEW 15 Dec 2018)

 KC902300.1| Dasychalina melior \\ $0.84195 \quad 0.76152$ EU702409.1|Amphimedon compressa \\ —KC902170.1| Haliclona walentinae \\ MK101133.1 Neopetrosia cristata UF 3859* \\ MK101135.1 Neopetrosia proxima UF 3856 \\ MK101137.1 Neopetrosia proxima UF 3858 \\ 1/55 MK101132.1 Neopetrosia proxima UF 3860 \\ DQ927319.1| Chalinula hooperi \\ KC902252.1| Neopetrosia proxima \\ KC902135.1| Neopetrosia exigua}

KF176618.1| Haliclona sp. BC7

_KF176614.1| Haliclona sp. BC1

KC902016.1| Haliclona mucifibrosa

DQ927315.1| Haliclona fascigera

KC902267.1| Haliclona sp. BM00-07065

AY734450.1| Haliclona oculata

— DQ927306.1| Haliclona cinerea

-DQ927313.1| Calyx sp. NIWAKD1132

AJ703889.1| Haliclona sp. OGL2003

KC902054.1| Haliclona manglaris

$0.53 / 54$

KC902356.1| Haliclona tubifera

DQ927310.1| Callyspongia sp. POR14635

KC902403.1| Haliclona curacaoensis

KC902171.1| Oceanapia isodictyiformis

—DQ927314.1| Callyspongia sp. NIWAKD1668

LEU702412.1| Callyspongia plicifera

$1 / 93$

L KC902402.1| Chalinula molitba

LAY734444.1| Haliclona sp. 5

KC902334.1| Neopetrosia rosariensis

$0.99 / 71$

9. KC902222.1| Petrosia strongylata

KC902101.1| Petrosia aff. hartmani

$0.521-$

DQ927308.1| Cribochalina vasculum

0.89996AJ703887.1| Haliclona amphioxa

0.99162 |KC902173.1| Petrosia weinbergi

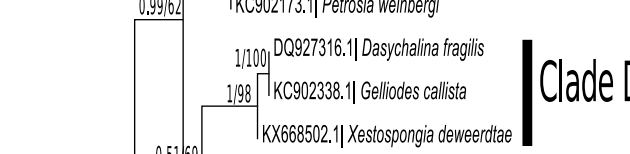

Clade A

0.5169

DQ927317.1| Oceanapia Sp. NIWAKD586

$0.78)$

_MK101136.1 Neopetrosia sigmafera UF $3857^{\star}$ _ EU095523.1| Haliclona sp. DS-2007a

0.93

$1 / 98$

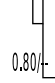

_AY621510.1|Xestospongia muta

0.80/-- KC902312.1|Xestospongia sp.

0.96/84 KC902039.1|Xestospongia bocatorensis KC901937.1| Neopetrosia carbonaria

KX668499.1| Haliclona plakophila

_KC902186.1| Janulum spinispiculum

1/100 DQ927322.1| Aka mucosum

0.93193

Kc902084.11 Siphonodictyon coralliphagum

KC901920.1| Oceanapia sp.

EF092264.1| Axinella corrugata 


\section{Figure 2}

Neopetrosia proxima (Duchassaing \& Michelotti, 1864)

In-situ images of Panama specimens (A) UF 3856 (B) UF 3858, and ex-situ image of (C) UF 3860 , with corresponding images of (D-F) tangential sections of the ectosome (LM); (G-I) perpendicular sections through the ectosome and choanosome (LM); (J-L) size and morphological variations of oxeas (SEM). 


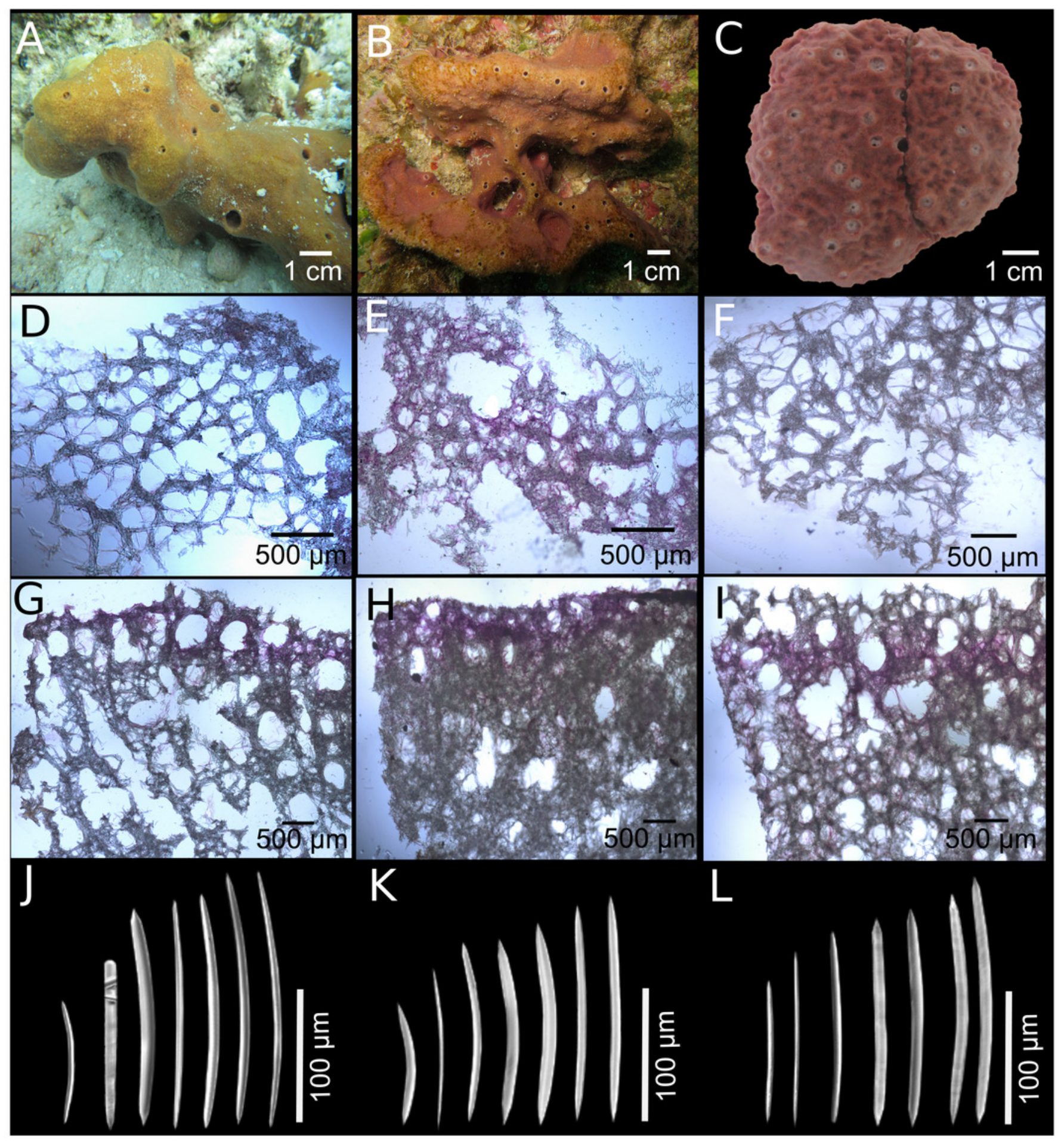




\section{Figure 3}

Neopetrosia dendrocrevacea sp. nov.

In-situ images of individual PPA 07 (A) and the holotype UF 3854 (B), both from Panama, and of the paratype ICN-MHN(Po) 0269 (C) from Santa Marta, Colombia, with corresponding (second and third rows) images of (D-F) tangential sections of the ectosome (LM); (G-I) perpendicular sections through the ectosome and choanosome (LM); size and morphological variations of oxeas from specimens collected in (J) Uraba, (K) Panama, (L) Cartagena, (M) Santa Marta, and (N) San Andrés Archipelago (LM). Scale bar of panel D is $100 \mu \mathrm{m}$. 


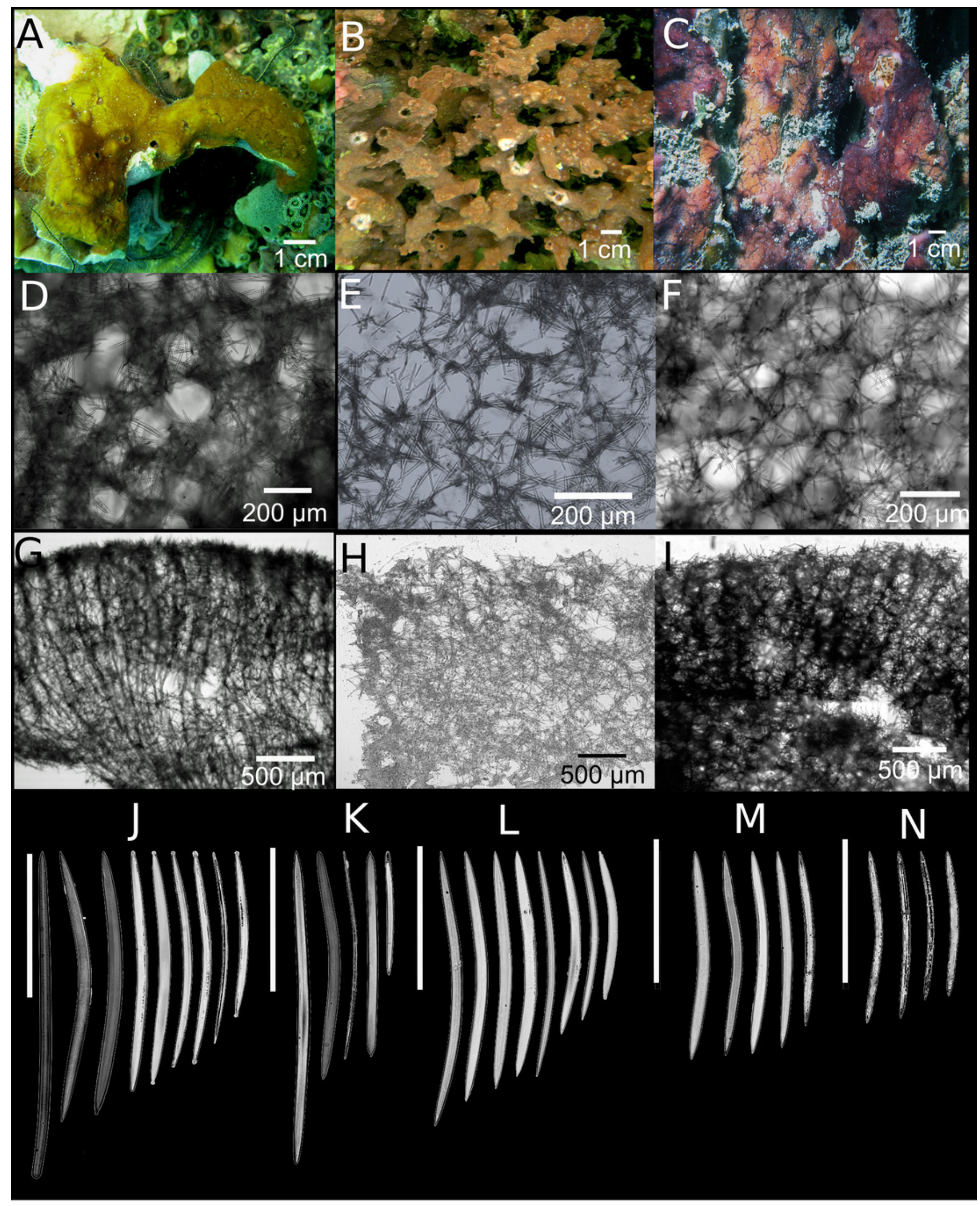




\section{Figure 4}

Neopetrosia cristata sp. nov.

Holotype (UF3859) (A) Ex-situ image of live sponge specimen; (B) tangential section of the ectosome (LM); (C) perpendicular section through the ectosome and choanosome (LM); (D) close-up of perpendicular section through the ectosome (LM); (E) close-up of perpendicular section through the choanosome (LM); (F) variation of oxeas (SEM). 

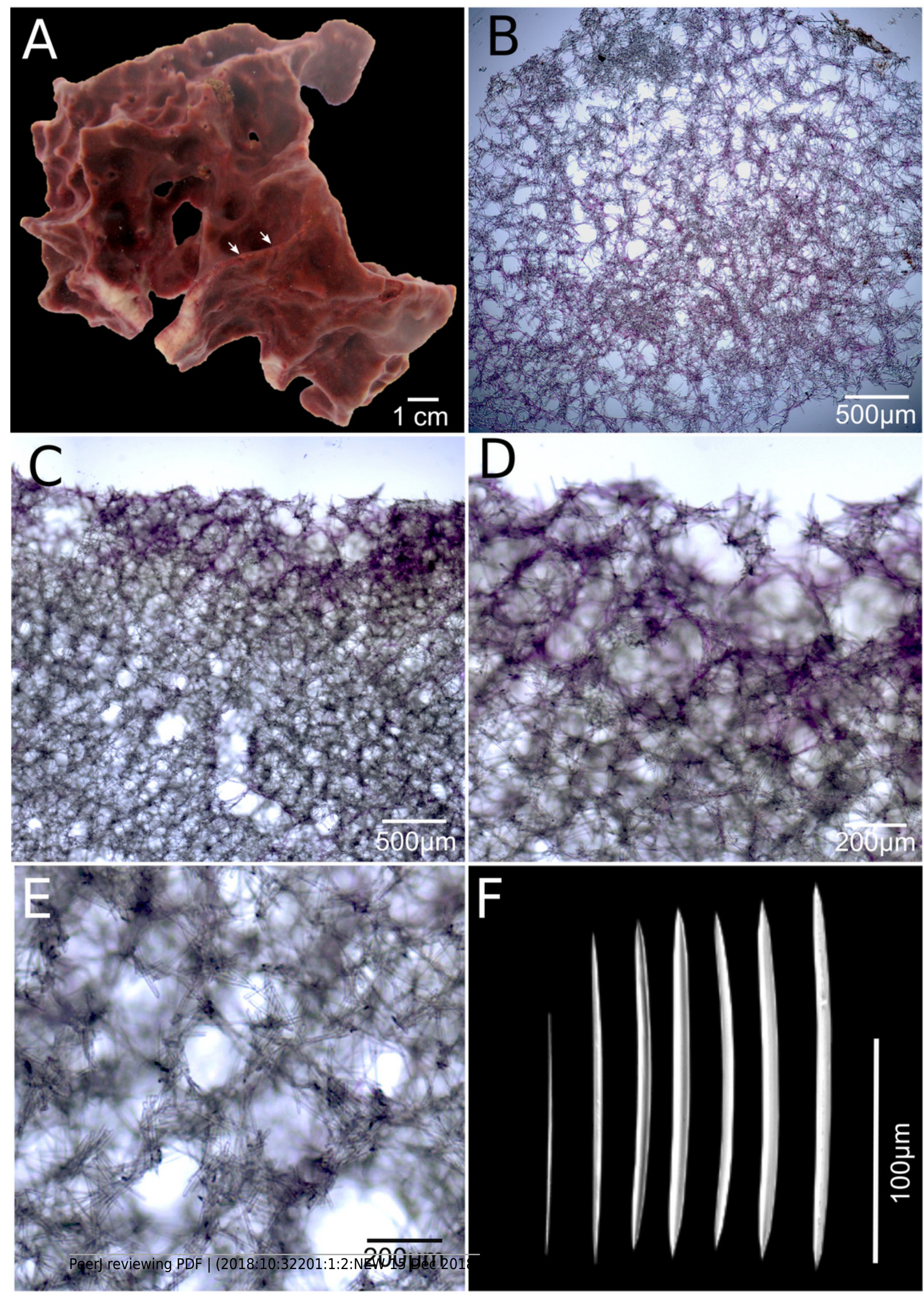


\section{Figure 5}

Neopetrosia sigmafera sp. nov.

In-situ images of the holotype UF 3857 (A) and individuals PPA 38 (B), both from Panama, and SZ-21 from Martinique (C), with corresponding images (D) of zoanthids; $(E, F)$ tangential sections of the ectosome (LM); (G) brooding larvae (arrows) (H, I) perpendicular sections through the ectosome and choanosome (LM); Size and morphological variations of oxeas and sigmas from (J) Panama, (K) Cartagena, (L) Martinique (LM). 


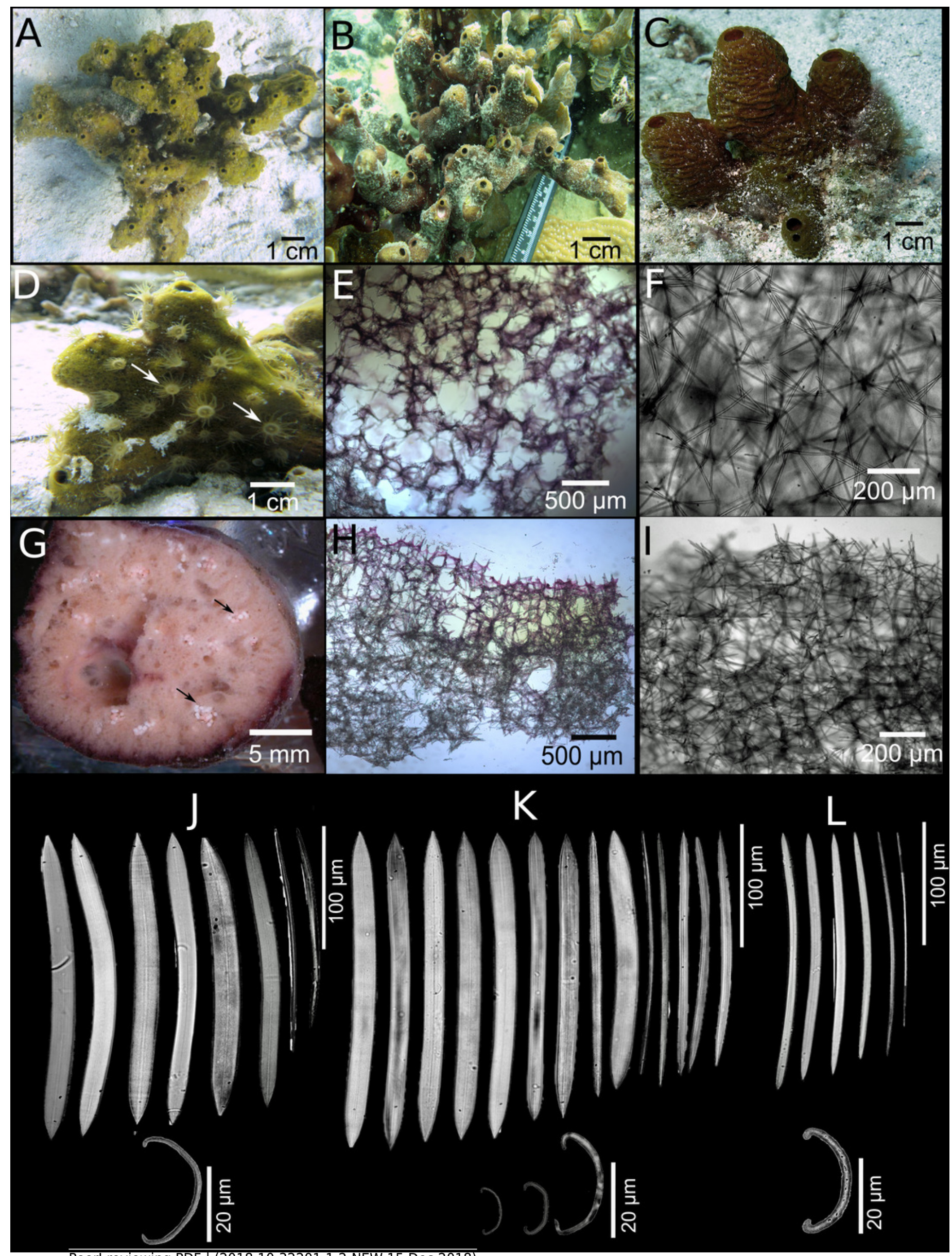




\section{Table $\mathbf{1}$ (on next page)}

Spicule measurements of oxeas (length and width) of Neopetrosia spp. described in this study.

Measurements are expressed as minimum-mean ( \pm 1 standard deviation) - maximum. $N=50$. $N A=$ not available. Uncat=uncatalogued sample 


\begin{tabular}{|c|c|c|c|c|}
\hline Species & Specimen & Location & Length $(\mu \mathrm{m})$ & Width $(\mu \mathrm{m})$ \\
\hline Neopetrosia proxima & UF 3856 & Bocas del Toro, Panama & 98-158.7 (土 19.9)-193 & $3-10.9( \pm 1.7)-11$ \\
\hline Duchassaing \& Michelotti & UF 3858 & Bocas del Toro, Panama & $92-146.6( \pm 14.0)-168$ & $3-9.0( \pm 1.7)-12$ \\
\hline \multirow[t]{4}{*}{ (1864) } & UF 3860 & Bocas del Toro, Panama & $117-159.3( \pm 14.0)-181$ & $6-9.3( \pm 1.1)-12$ \\
\hline & Uncat. PPA 35 & Bocas del Toro, Panama & $75-N A( \pm \mathrm{NA})-205$ & $2.7-N A( \pm \mathrm{NA})-10.7$ \\
\hline & Uncat. PPA 37 & Bocas del Toro, Panama & $85-N A( \pm \mathrm{NA})-167$ & $1.7-N A( \pm \mathrm{NA})-12.7$ \\
\hline & INV POR1306 & Old Providence, Colombia & $110-N A( \pm \mathrm{NA})-150$ & $2.5-N A( \pm \mathrm{NA})-5$ \\
\hline Neopetrosia & UF 3854 Holotype & Bocas del Toro, Panama & $91-165.2( \pm 15.9)-188$ & $2.8-7.4( \pm 1.5)-10.5$ \\
\hline \multirow[t]{9}{*}{ dendrocrevacea $\mathbf{s p . ~ n o v . ~}$} & Uncat. PPA 07 & Bocas del Toro, Panama & $111-156.5( \pm 14.6)-181$ & $4.5-6.6( \pm 0.9)-8.9$ \\
\hline & INV POR0535 & Urabá, Colombia & $134-171.4( \pm 12.9)-198$ & $4.4-7.4( \pm 1.0)-9.4$ \\
\hline & UF 3854 & Bocas del Toro, Panama & $91-165.2( \pm 15.9)-188$ & $2.8-7.4( \pm 1.5)-10.5$ \\
\hline & INV POR 1336 & Cartagena, Colombia & $133-165.1( \pm 12.9)-189$ & $4.6-6.4( \pm 0.6)-7.7$ \\
\hline & INV POR1337 & Cartagena, Colombia & $139-164.4( \pm 12.9)-192$ & $4.1-7.3( \pm 1.3)-9.8$ \\
\hline & ICN-MHN(Po) 0269 & Santa Marta, Colombia & $130-151.6( \pm 9.4)-168$ & $5.0-6.5( \pm 0.9)-9$ \\
\hline & INV POR1335 & Santa Marta, Colombia & $103-147.8( \pm 12.3)-169$ & $4-6.5( \pm 1.1)-9$ \\
\hline & INV POR1333 & San Andrés, Colombia & $86-119.3( \pm 11.3)-150$ & $3.5-4.8( \pm 0.6)-6$ \\
\hline & INV POR1334 & San Andrés, Colombia & $114-130.1( \pm 7.7)-149$ & $5.1-3.8( \pm 0.6)-7$ \\
\hline $\begin{array}{l}\text { Neopetrosia cristata } \mathbf{s p .} \\
\text { nov. }\end{array}$ & UF 3859 Holotype & Bocas del Toro, Panama & $121-142.1( \pm 9.8)-163.2$ & $2.1-7.2( \pm 1.7)-9.6$ \\
\hline \multirow[t]{9}{*}{$\begin{array}{l}\text { Neopetrosia sigmafera } \mathbf{s p .} \\
\text { nov. }\end{array}$} & UF 3857 Holotype & Bocas del Toro, Panama & $173-235.9( \pm 14.1)-259$ & $6.5-13.6( \pm 1.5)-15.9$ \\
\hline & Uncat. PPA 36 & Bocas del Toro, Panama & $174-226.5( \pm 12.4)-248$ & $6.5-14.2( \pm 2.4)-17.6$ \\
\hline & Uncat. PPA 48 & Bocas del Toro, Panama & $196-232.7( \pm 10.4)-233$ & $6.9-13.5( \pm 1.9)-15.5$ \\
\hline & INV POR 1338 & Cartagena, Colombia & $203.5-237.4( \pm 11.8)-255$ & $5.8-14.0( \pm 2.8)-14.0$ \\
\hline & INV POR 1339 & Cartagena, Colombia & $201.9-240.2( \pm 14.5)-260$ & $5.0-17.0( \pm 2.9)-17.7$ \\
\hline & ICN-MHN(Po) 270 & Cartagena, Colombia & $201.9-240.2( \pm 14.5)-260$ & $5.0-17.0( \pm 2.9)-17.7$ \\
\hline & Uncat. SZ-20 & Martinique & $153-197.2( \pm 10.6)-219$ & $6.9-8.2( \pm 0.6)-9.3$ \\
\hline & Uncat. SZ-21 & Martinique & $115-204.6( \pm 18.6)-230$ & $6.8-8.8( \pm 0.7)-10.3$ \\
\hline & Uncat. SZ-23 & Martinique & $130-190.4( \pm 13.2)-190$ & $4.9-6.8( \pm 1.0)-8.6$ \\
\hline
\end{tabular}




\section{Table 2 (on next page)}

Lengths of sigma of Neopetrosia sigmafera sp. nov.

Measurements are expressed as minimum-mean-maximum 


\begin{tabular}{cccc}
\hline Specimen & Location & Number of sigmas & Length $(\mu \mathrm{m})$ \\
\hline UF 3857, holotype & Bocas del Toro, Panama & 20 & $7.6-22.0-27.0$ \\
Uncat PPA 36 & Bocas del Toro, Panama & 15 & $12.7-22.6-29.3$ \\
Uncat PPA 38 & Bocas del Toro, Panama & 13 & $20.6-24.4-29.5$ \\
INV POR 1338 & Cartagena, Colombia & 10 & $11.0-20.2-28.7$ \\
INV POR 1339 & Cartagena, Colombia & 10 & $8.7-15.1-30.2$ \\
ICN-MHN(Po) 270 & Cartagena, Colombia & 10 & $11.2-19.2-31.4$ \\
Uncat SZ-20 & Martinique & 10 & $20.6-24.4-29.5$ \\
Uncat SZ-21 & Martinique & 6 & $10.0-21.2-28.7$ \\
Uncat SZ-23 & Martinique & 10 & $9.3-19.8-31.0$ \\
\hline
\end{tabular}

1 